\title{
ごみ焼却発電・熱利用
}

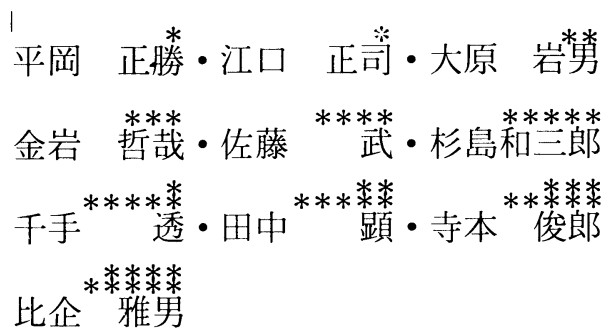

\section{1. アムステルダム北部ごみ焼却場}

\section{1 オランダにおけるごみ焼却施設概要}

オランダ全土におけるごみ焼却施設は11施設でその うちボイラと発電施設を有する 4 大施設で，全焼却能 力の約 $50 \%$ を有している.

てれらはそれぞれ自治体またはその共同体で管理運 営されてきたが，1979年 8 月に公布された法律により 80 年秋から州（全11州）がその責任を負うようになった.

4 大施設之はつぎのあのである.

$$
\begin{array}{ll}
\text { アムステルダム市 } & 40 \text { 万 } \mathrm{T} / \text { 年 } \\
\text { ロッテルダム市 } & 30 \text { 万 } \mathrm{T} / \text { 年 } \\
& 60 \text { 万 } \mathrm{T} / \text { 年 }
\end{array}
$$

(最新 1974 年建設)

デンハーグ市２5万 T/年

その他 7 施設 約 6 万 $\mathrm{T} /$ 年

\section{2 オランダにおける電力供給方式}

各州に 1 汃以上の発電施設を有し, 州の責任に押 いて電力を供給しており，てれらの調整はアルンへム 市（Arnhem）にある電力供給企業連合体 (SEP) が 受け持っている。また，ての SEPは欧州各国間の調整 （西独, フランクフルト市にコントロールセンタがある） あ行っている.

ゴミ焼却場で発電された電力は，市の電力供給局を 経て州の SEP 亿売却され各需要家に給電される.

\section{3 アムステルダム市ごみ焼却場}

\subsection{1 概 要}

1966 年アムステルダム本清掃局によって，でみ烧却 炉之, 高压・高温蒸気による高効率の発電施設として 計画され，1969 年に市北部で，運河に面しガス火力発 電所に隣接した地に建設された。現在，市の人口は， 約100万人で，排出されるでみの量は約50万T/年であ る. このうち約73〜74\%が一般でみで，残りが食堂な よ゙から排出される一般でみ之同等の産業廃棄物である。 てれらのでみの焼却場への搬入は, 約 $25 \%$ が運河を利 用した専用はしけによっており, 燒却場には専用岸壁 が設けられている.

\subsection{2 施設概要}

\section{（1）でみ焼却・発電施設}

陸上抢よび水上輸送されたでみは容量約 $5,300 \mathrm{~m}^{3}$ の ごみピットに眝蓄され（図-1），2 基のでみクレーン で 4 基の焼却炬に投入される.燃䡒ガスはボイラにて 熱交換し，減温されて電気集じん機を経て導引通風機 により高さ $100 \mathrm{~m}$ の煙突から排出される。一方焼却灰 は，灰破砕機を経て鉄金属を選別分離しバンカに眝蓄 され主にはしけによって搬出される。また，ボイラで 発生した蒸気は, 過熱蒸気となりスチームタービンに 送られて発電され，排気はコンデンサを経て再び給水 上して循環する。でみ焼却炉設備を図-2に，給水蒸気系

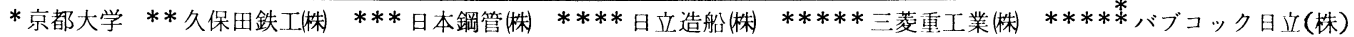

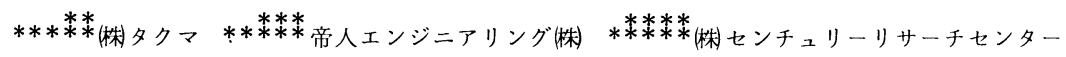


統を図-3に示した。

(2) 粗大廃木材破砕設備

焼却設備とは独立して設けられ，破砕物はコンベヤ

で接岸しているはしけに積み込まれて運送される。

\subsection{3 主要計画值（ごみ焼却施設）}

ごみ低位発熱量 $1,760 \sim 2,250 \mathrm{kcal} / \mathrm{kg}$ （当日どみ> $2,000 \mathrm{kcal} / \mathrm{kg}$ )

焼却総量 40 万 $\mathrm{T} /$ 年

（a）焼却設備

炉マルチン式 (炉巾 $6.3 \mathrm{~m}$, 火床面積 $53 \mathrm{~m}^{2}$ )

能力 $16 \sim 20 \mathrm{~T} / \mathrm{H} \times 4$ 基

運転方法 蒸気量検出による自動燃焼

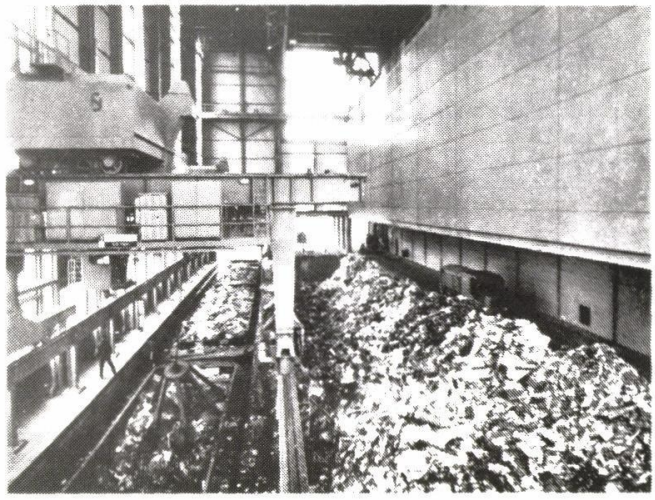

図ー1 ごみピット（左側に見えるのがはしけである）
方式 (1974年改造)

制御対象; スト一力速度, 燃焼用 空気

緊急用補助燃焼用オイルバーナ（785 Kg / H×4 台）付

(b) ボイラ

形式

$\mathrm{BdW}$ 形自然循環式水管ボイラ 1 基 $/ 1$ 炉

蒸気圧力 $43 \mathrm{Kg} / \mathrm{cm}^{2}$ (蒸気ドラム)

蒸発量 $43 \mathrm{~T} / \mathrm{H}$ (最大, 1 基当たり)

過熱蒸気温度 $410^{\circ} \mathrm{C}$

(c) 発電設備

○蒸気タービン 抽気復水式 2 基

蒸気圧力 $41 \mathrm{Kg} / \mathrm{cm}^{2}$

蒸気温度 $405^{\circ} \mathrm{C}$

回転数 3,000RPM

発電機交流夕ーボ式 2 基

経済出力 $16 \mathrm{MW}$ ( 1 基当たり)

定格出力 $20.5 \mathrm{MW}$ (1 基当たり)

(d) その他の装置

電気式集じん装置 保証值 $<100 \mathrm{mg} / \mathrm{Nm}^{3}$

\subsection{4 現在の運転概要}

訪問時の運転基数 2 基（1 基定期整備中， 1 基停

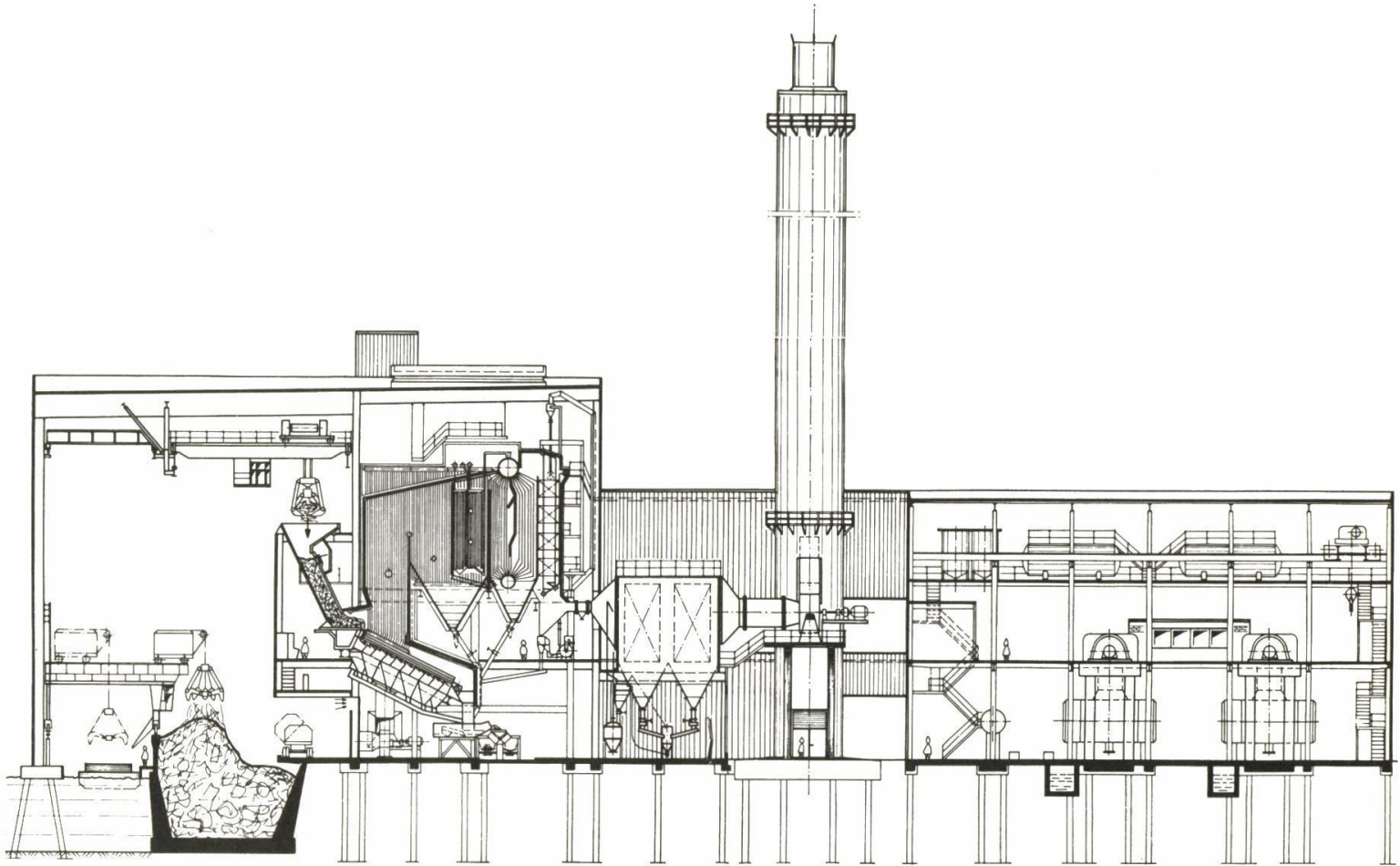

図-2 ごみ焼却炉断面成 


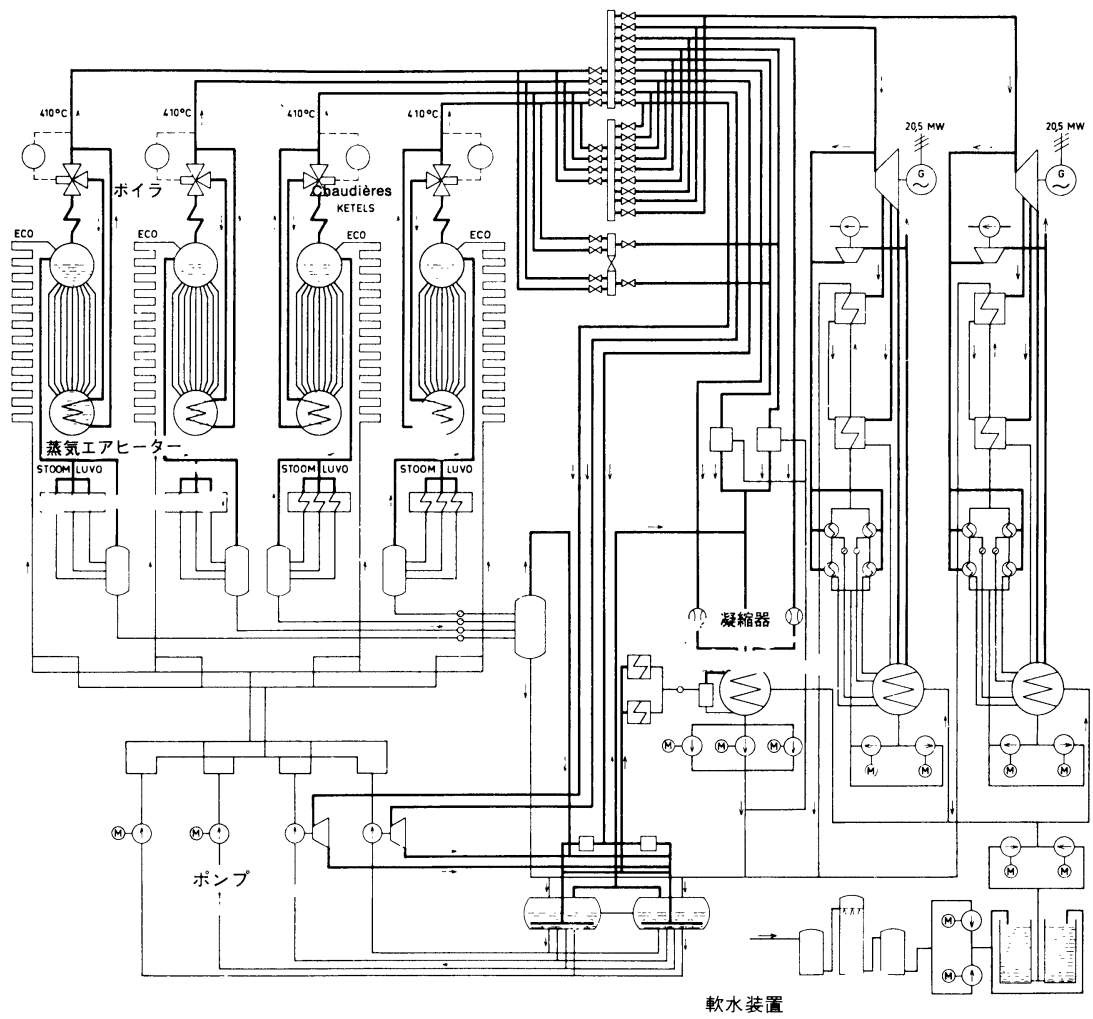

図- 3 給水・蒸気系統

止中)

蒸気压力 $41 \mathrm{Kg} / \mathrm{cm}^{2}$

蒸気量 $40 \mathrm{~T} / \mathrm{H}$

蒸気温度 $360^{\circ} \mathrm{C}$

発電量 (売電量) $23 \mathrm{MW} \pm 10 \%$ (年間全量平均)

(参考) アムステルダム市全域電力消費量（年間平均）

$\begin{array}{ll}0 \text { 時 3 時 } & \text { 約 } 165 \mathrm{MW} \\ \text { 日中 } & \text { 約 } 660 \mathrm{MW}\end{array}$

年間稼動率 約70\%（年間全焼却量40万 T ）

年間を通じて施設全体の休止は, クリスマス，イー スタなどの特定の休日のみ.

\subsection{5 公害対策および関連事項}

公害規制はばいじん排出量 $\left(<100 \mathrm{mg} / \mathrm{N} \mathrm{m}^{3}\right)$ のみであ

る. しかし, 塩化ビニル系樹脂の量む增加し $\mathrm{HCl}$ ガス による各種設備に及ぼす被害が発生している.

(1) ばいじん量

運転実績 $<100 \mathrm{mg} / \mathrm{Nm}^{3}$

(2) $\mathrm{HCl}$ ガス

測定值がなく実数は不明各種設備に対する影響はつ

ぎのとおりである.

ボイラ過熱管（炭素鋼 肉厚 $3.5 \mathrm{~mm}$ ) (高温域腐蝕)
炻中に対して中央部が特に腐蝕減肉が著しく 12 月月 で下部Uベンド部分を切継交換，その他は60か月で交 換している，腐蝕低減対策として過熱蒸気温度を計画 值の $410^{\circ} \mathrm{C}$ に対し $360^{\circ} \mathrm{C}$ にげている.

排ガス系（低温域腐蝕）

ガス温度の低下により生ずる凝縮水中の $\mathrm{HCl}$ により 腐蝕が進行している。特に煙突に顕著に発生しており, ガス温度を $175^{\circ} \mathrm{C}$ 以上維持させて腐蝕防止を計って いる.

\subsection{6 現在の運転管理}

人員 165 人 (うち工場勤務者 161 人)

運転経費（精算値）1,800万ギルダ/年.

（45ギルダ/ごみ T, 約 5,400 円）

内訳(1)運転総経費 2500 万ギルダ/年 KWH約 6 円 ) 内訳 人件費 900 万ギルダ/年

$$
\left(\begin{array}{l}
\text { 給料 } \quad 560 \text { 万ギルダ/年 } \\
\text { 保険他経費340万ギルダ/年 }
\end{array}\right)
$$

資本費（償却費，金利，税金，保険など） 600万ギルダ/年

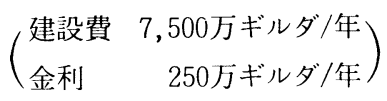


整備費, 動力費, 消耗品費他

1,000万ギルダ/年

（消費電力 $2.0 \mathrm{MW}$ )

主要設備償却期間

スチームタービン 30 年

焼却炉，ボイラ 20 年

(2) 電力売却収益 700 万ギルダ/年

( 0.05 ギルダ/KWH約 6 円)

\subsection{7 焼却残渣とその処分}

焼却残渣量 焼却ごみ量対比 $25.31 \%$

内訳 鉄分 $2.69 \%$ 売却費 30 ギルダ/T

(約3,600円)

フライアッシュ分 $3.05 \%$ 売却不能, 埋立処分

灰分 破砕選別分1 5.36\%

売却費 5 ギルダ/ T（約600円）

(路床, 整地用埋立材に使用されている)

選別残分 $4.1 \%$ 売却不能, 埋立処分

\section{4 あとがき}

国状とはいえ，市のでみ燒却処理事業之市打よび州 による電力供給事業を直結させエネルギの再利用を計 り，また運河を輸送手段に加えて冷却水としての用役 に利用し，有機的に結合させ，更に選別金属の回収売 却のみならず，焼却兏を路床や整地用代材として売却 し，運転の自動化を増設して運転経費の軽減を計って いる. てれらを10数年以前に計画し実行している点に ついて, わが国む行政, 電力会社を始め国民的問題之 して大いに考えねばならないと思う。

また，でみ質の変化 (特にPVC系の増加) は著しく, こ れに伴う設備保護を公害対策以前に真剣に取り組んで おり, $\mathrm{HCl}$ ガス対策の必要性を強調すると共に発電効 率を低下させても, ボイラ蒸気過熱管保護のために, 蒸 気圧力を $25 \mathrm{Kg} / \mathrm{cm}^{2}$, 過熱蒸気温度を $270^{\circ} \mathrm{C}$ 以下にす べきであるてとを付言していた。

これらの見聞事項を参考とし，廃棄物処理とェネル ギー問題を原点に戻って考え直さ水ばならないと痛感し た. 最後にオランダ国の清掃事業とエネルギー対策の 一層の発展を心から祈りたい。

\section{資 料}

1. VUILVERBRANDING AMSTERDAM AMSTERDAM- NOORD PAPAVERWEG 59

\section{2. シュツットガルトミュンスター発電所}

\section{1 概 要}

ミュンスター発電所は, ネッカル川（Neckar）左岸
にあるシュツットガルト市ミュンスターに位置し，1908 年に発電を開始した。今日のような形式になったのは, 主に，第 2 次世界大戦以降である.

全体のプラントは, 大きく 3 つの部分に分けられる. すなわち, 発電所 1 ( 4 つのボイラ, 4 つのタービン), 古い発電所 2 ( 1 つのボイラ, 1 つのタービン), そし てでみ焼却発電所 3 （３つのボイラ）である.

乙の発電所では, 全てのボイラは, 1 つの共通の蒸 気へッダーに $60 \mathrm{bar}, 500^{\circ} \mathrm{C}$ の蒸気を供給し, さらに, 蒸気タービンや地域暖房装置も全ててのへッダーに接 続されている.

乙の発電所は, 3 相交流を発生させるほかに, 都市 部（Freiberg und Nord/West）の配管網に，暖房用 の温水を供給している。またすでに 1935 年より，4 bar 蒸気網に蒸気を供給している. 当時, 焼却炬は, 20 $\mathrm{T} / \mathrm{H}$ の処理能力のあのが 2 炉あり, 年間処理量は, 13 万 $\mathrm{T} /$ 年, ごみO低位発熱量は, $1300 \mathrm{kcal} / \mathrm{kg}$ であっ た. 1972 年に, $20 \mathrm{~T} / \mathrm{H}$ の処理能力を持つ炉が增設さ れ, 現在, 年間処理量 25 万 $\mathrm{T} /$ 年, でみの低位発熱量 $2000 \mathrm{kcal} / \mathrm{kg}$ （1979年実績）に達している.シュッッ トガルト市より持込まれるごみは, $2 / 3$ が家庭から出る あのであり, $1 / 3$ が産業廃棄物である. 産業廃棄物は, 家庭でみと同種のあのとされ, 油・污泥・病院廃棄物 等は, 持込みが禁止されている.

この発電所のでみ焼却プラントの特色は, ごみを単 独で燃燒させて蒸気を発生させるのではなく，1炉に 2つの燃焼室を持ち，1つは, でみの燃焼用, 他方は, 燃料（主に重油）の燃焼用としているとてろにある. てのようなシステムのため, 蒸気条件を, 高温・高圧 (60bar, $\left.500^{\circ} \mathrm{C}\right)$ 亿維持できるむのと考えられる.し かし, 近年のでみ発熱量の上昇により, 旧型の 2 炝で は燃料用燃焼室を取り払って, 現在, ごみのみの燃焼 で蒸気を発生させており，燃料の節約に貢献している そうである。(1972 年に作られた新型炉は，1/2でみ， 1/2重油燃焼で現在運転されている)。

ミュンスター発電所は, 将来大規模な近代化処置を 計画している. それは 2 段階に分けて行われる予定で, そのつど, 40MW タービン 1 基, $150 \mathrm{~T} / \mathrm{H}$ ボイラ 1 基 を設置するてとになっている.

ミュンスター発電所は, TWS (Technische Werke der Stadt Stuttgart) という, 公社形式のエネルギー 供給会社の, 1 工場である.次にての TWSについて記 述する. 


\section{2 TWS}

\subsection{1 電力供給}

TW S は, 全部で 238 kmの地域に電気を供給して いる。供給地域は, シュッットガルト市の他に Marbach市ならびにLuwwigsburg-Poppenweiler と Mundelseimの町村を含みそ乙には, 約 595,000 人の居 住者がいる.

TW S は, 原子力発電抢よび従来のガスタービンや 蒸気夕ービンによる発電, ならびに, 水力発電上外部 からの受け入机よって, 電力需要を力バーしている. 外部電力の供給者は, Schwaben エネルギー供給株式 会社（EV S ）である.

電気の有効放出量は, 全供給地域において, 1978 年 度で2,591 GWHに達し, 最大負荷量は580 MWである。

T W S が，自由に制御できる三相交流出力は，全部 で 938 MWである(1979 年).

電気需要のほぼ半分を, NeckarwestheimとObrigheim にある 2 つの原子力発電所ががーしている. TW Sは，乙れらの株式資本のそれぞれ14\%，32\%を 出資している. Obrigheim 原子力発電所 $(\mathrm{KWO})$ の総出力は, 最高 $328 \mathrm{MW}$ であり, TW S は出資分の 45MW（⒊328 MW $\times 14 \%$ ! $100 ）$ が自由に使える.

Neckarwestheimでは, 1976 年に, 経営に連合体 I（Block I ）を取り入れた.そして, 炉は KWO と同 じく加圧水型を採用し, 全部で約 $810 \mathrm{MW}$ の出力を 持っている. GKN (Gemeinschaftskern kraftwerkenechar）の連合体 I に拈るTW S の出資分は 253 MWである.

シュツットガルト市域内にある，ミュンスターと Geisburg の雨化石燃料暖房発電所は, それぞれ, 164 MW, 292 MW, の出力がある. この2つの発電 所は，おもに平均的な負荷抢よびピーク負荷に対応す るものとして設置されている，乙れら以上に重大な使 命をもつあのとして, 予備のために, 双方にガスター ビンプラントが設置されている. 出力は合わせて 125 MWである.

Reutlingen 近くの Gleim 揚水発電所は, ピーク負 荷時の重大な援助を行う発電所である.

\subsection{2 熱供給}

4 つの暖房用水管網および蒸気管網は，それぞれ $92 \mathrm{~km}, 16 \mathrm{~km}$ である. そして, それらの熱供給に伴う総 接続負荷は $675 \mathrm{MJ} / \mathrm{s}\left(161 \times 10^{3} \mathrm{kcal} / \mathrm{s}\right)$ に達する. ミュンスター発電所と Gaisburg 発電所が, 熱の必要 量のほぼ全てを供給する（1978 年度：4573 TJ）。需要
のわずかな部分を, Marienstra引電気貯蔵暖房工場が, カバーしている. 夜間の割安な電気料金によって水を $180{ }^{\circ} \mathrm{C}$ ま゙加熱し, 昼間にその熱を放出するシステム である.

\section{2.3TWSとシュツットガルト市およびミュンス ター発電所との関係}

TW S は，その名が示す通り株式会社であるが，そ の株の大部分を, シュツットガルト市が保有している. ミュンスター発電所は, T W S の 1 発電工場にすぎな いが,でみ焼却発電を行っているため特異な存在となっ ている.ごみは, シュッットガルト市の委託によって, ミュンスター発電所で処理され, 市は発電所に委託料 を支払う（委託料 1000 万マルク/年 $\div 12$ 億 8000 万円/ 年). また焼却灰中より回収された鉄は, 巾によって工 場より運び出され, 市が販売している.（鉄の販売価 格30 DM/T $\div 3,840$ 円/T）焼却灰およびフライアッ シュも，市によって工場より運び出され，市によって 路盤材などとして販壳されている（現在，ての仕事は 市が他の会社に委託してやらせているが，市の利益は まったくないそうである).

\section{3 ボイラ装置}

\section{3.1 ボイラ}

発電所には, 8 つボイラが取り付けられており, その能力は全部で $985 \mathrm{~T} / \mathrm{H}$ である.

ボイラK12，K13，K15とK24は，石炭燃焼炉に取 り付けられている.K14のボイラは, 天然ガス一重油 混焼炉に取り付けられている。

K27，K28，K29のボイラは，でみと重油の燃焼室 を組み合わせた炉に設置されている. 新しいごみ焼却 ボイラK 27 は, 油燃焼と同時にごみ屯燃焼させて運転 されている.乙れに対し, 古いボイラK28，K29は， 純粋にでみだけを燃焼させて, 最小の蒸気発生を行っ ている.

ボイラK $27, \mathrm{~K} 29$ の炉の火格子は, デュッセルドル フ方式のドラム型のもので, VKW 社の製品であり, ボイラK28のそれは, マルチン社の製品である. 蒸 気系統を図- 4 亿示した。

8 つの全てのボイラから出る排出ガスは, 除塵装置 すなわち電気集じん機を通っで净化され，180 mの高 さを持つ集合煙突により大気に排出される。 この工場 では, 塩化水素などの大気污染物質に対しては, 何ら 対策は行っていない.

\subsection{2 ごみ焼却炉のボイラの腐食対策}

熱回収の効率低下をもたらす，ダストによる伝熱面 
の污れ, 塩化水素による伝熱管の腐食を防ぐため下記 の考慮を払っている.

（1）伝熱管のピッチを $180 \mathrm{~mm}$ 以上とし，インーライン 配列.

（2）ガス速度を遅くとる. 例えば火炉出口の水冷壁入 口部で $6 \mathrm{~m} / \mathrm{s} よ り ~ 3.5 \mathrm{~m} / \mathrm{s}$ に低減して効果を得て いる.

(3) 伝熱管の温度は $350^{\circ} \mathrm{C}$ 以下がよい。

(4) 低温燃焼ゾーンでは，スタッドを打ちプラスチッ ク耐火材をライニングしている.( 1 例として,10 $\phi \times 16$ $\ell m m$ のクロマルー10なるスタッドを 2,500 本 $/ \mathrm{m}^{2}$ 打ち, 耐火材をライニングしている.)

(5) ライニング材としては, 粘土とバインダーと50〜 80\% SiC の混合材料が良い. また, 熱伝導度もすぐれ ている.

\section{4 蒸気タービン}

ミュンスター発電所には, 5 つの違った型の三相交 流タービンがあり, 全部で $102 \mathrm{MW}$ の出力がある. 乙 のうち 3 つのタービンが, 背圧または抽気復水タービ ンとして，電力一熱結合型で使用されている.

\section{5 ガスタービン}

ミュンスター発電所の敷地内で, 蒸気発電所の横に, 3 つ互いに独立したユニットで構成されたガスター ビンプラントが設置されており, その発電能力は, 全 部で70 MW である.

このプラントは, 早い立上り能力を備えており, 他
の発電所の操業中止時の, 供給確保用として働いて いる. また，ピーク電力を越えた需要がある時に, 稼 動される。

\section{6 ごみ焼却炉}

1965 年のごみ焼却場運転開始より，ほぼ 300 万Tの ごみを燃やした。

1978 年には，3つの炉でほぼ 25 万T，すなわち， $730,000 \mathrm{~m}^{3}$ に達した. 乙れは, シュッットガルト市のでみ の86\%にあたる. 市のでみの10\%は, 委託者によって 埋め立てられ，4\%は，コンポスト化された。

\section{7 あとがき}

火力発電所とごみ焼却設備がコンバイン化したシス テムの例であり, 発電所がごみ焼却の業務も行ってお りまた，でみのあつエネルギーの有効利用を10数年 あ前から実施していることなよ゙ドイッ人らしい合理的 な発想であると痛感した。

これらごみ焼却ボイラは発電用ボイラとしての役目 あ有しているため, 重油之の混焼方式であり, 高温・ 高圧の蒸気条件で操業しており高い熱効率を得ている ところあわが国とは異なったシステムである.

このようなでみ焼却発電の考え方, エネルギーの有 効利用法, 腐食への対応, 炉形式の異なるプラントの 選定なよ゙大いに参考になった。

\section{資 料}

1. Dampfkrafkwek Munster und Müllverbrennungsanlage (Technische Werke der Stad $t$ Stuttgart AG-TWS)

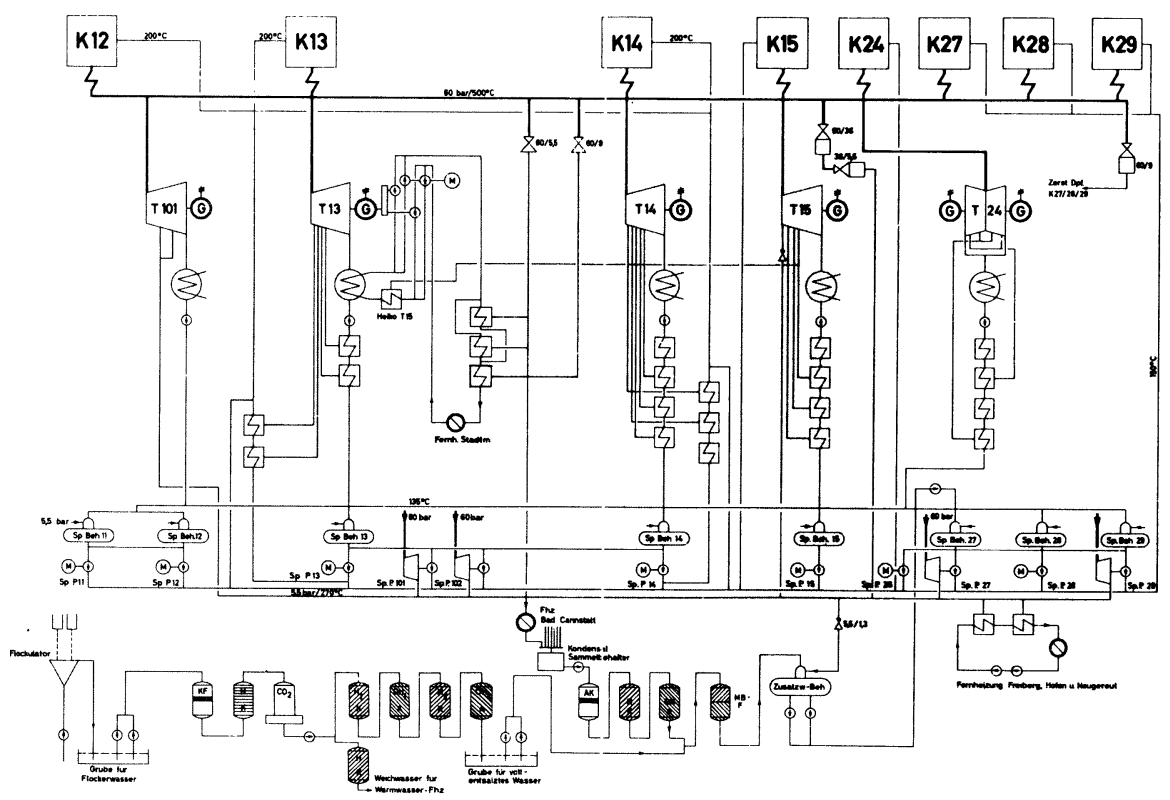

図-4 蒸気系統図 
-Panfurette

2. F.Nowak; Corrosion Problems in Incinerators

3. F.Nowak; Consideration in the Construction of Lar. ge Refuse Incinerators, Combution, Novemher ( 1968 ) incine ation

\section{3. ミュンヘンごみ焼却発電所}

\section{1 ミュンヘン電力会社}

\subsection{1一般概要}

ミュンヘンにおけるごみ処理は欧州の他の大都市と同 様, ごみ焼却用ストーカを併置した熱併給発電所で委 託焼却され，その管理運営は书の出資によって設立さ れたミュヘン電力会社により行われている. しかし他 の都市に較べると, ごみ焼却能力, 発生電力, 熱供給 能力が大規模で複合化されており，その状況を各施設 型式別に各種資料により整理してて表 1 亿示す。本表か ら, ごみ混焼熱併給発電所の発電能力がミュンヘン電 力会社全体の $50 \%$ 程度を占め, かつ, ミュンヘン全体の でみ処理の総てを担っているてとから，如何に重要な 都市施設であるかを理解することができよう。

\subsection{2 電力需要の状況}

ミュヘン市に打ける電力消費量の推移を図- 5 に示 すが，経済の発展と共に急激な上昇力ーブを画いて いる.

これらの需要に対する各火力発電所の負荷配分の一 例を図- 6 に示す.本図は, 1977 年の伴間ピーク発生日 の状況であって平均的な傾向とは言い難いが，ピーク と最小負荷は時間によって2 倍にも達し, でみ混焼火 力の停止起動も余儀なくされている. 乙れら電力需要 増加, ピーク時対策ならびにごみ焼却処理対策しして ガスタービン発電所や, 負荷変動に影響されないでみ 専焼発電所が以下の如く建設中である.

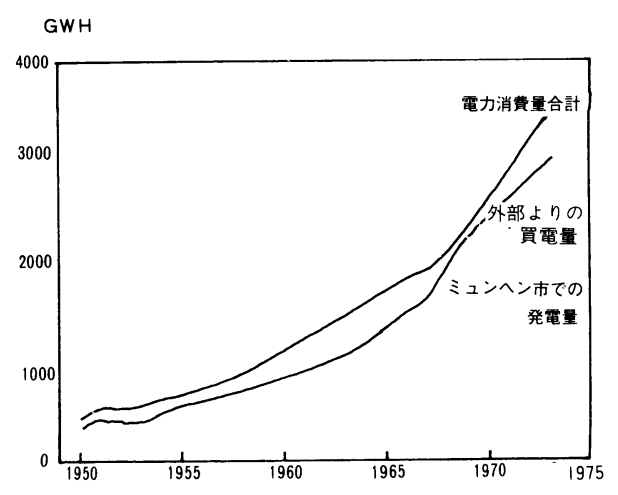

図-5 電力消費量の推移

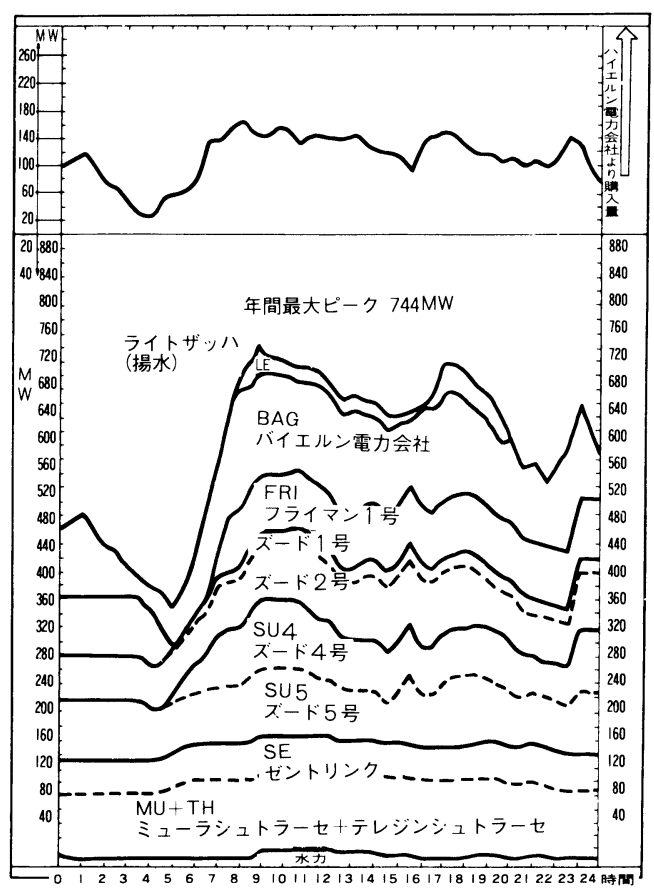

図-6 発電所別電力負荷バターン

年間最大ピーク発生月（1977 作 12 月 5 日）

表 1 ミュンヘン電力会社施設能力一覧表

\begin{tabular}{|c|c|c|c|c|}
\hline 型 式 別 施 設 & 施 設 数 & $\begin{array}{c}\text { ごみ焼却能力 } \\
\mathrm{T} / \mathrm{D}\end{array}$ & $\begin{array}{c}\text { 発電能力 } \\
\mathrm{MW}\end{array}$ & $\begin{array}{c}\text { 熱供給能力 } \\
\text { Gcal/H }\end{array}$ \\
\hline $\begin{array}{l}\text { ごみ混焼熱併給発電所 } \\
\text { (北部180MW, 南部248MW） }\end{array}$ & 2 & 4,080 & 428 & \\
\hline $\begin{array}{l}\text { 熱併給発電所 } \\
\text { (シュー79MW，テレジン44MW) }\end{array}$ & 2 & - & 123 & 1,165 \\
\hline 熱併給ガスタービン発電所 & 2 & - & 204 & \\
\hline 熱供給所 & 5 & - & - & 315 \\
\hline 水力発電所 & 5 & - & 93 & - \\
\hline 合 & 17 & 4,080 & 848 & 1,480 \\
\hline
\end{tabular}

注）文献により, 若千差異あり 


\section{1.3 増設発電所の状況}

(1) ガスタービン発電所（南部発電所内）

ピークロード対策として起動時間が早い（9 分）ガ スタービンプラントが南部発電所内に建設中で, 近く 稼動に入る予定である. 南部発電所は後述の高圧のご み混焼熱併給火力の他に, 旧施設として, 中圧の熱併 給火力発電所が設置されていたが，乙れを徹去して世 界最大級の主プラントを建設するもので，入口ガス温 度 $920^{\circ} \mathrm{C}$ の゙スタービン 2 基と, 42 ata の廃熱ボイラ による蒸気タービン 1 基より構成されるコンバインド サイクルプラントである. 能力としては,

$\begin{array}{llrr}\text { 発電出力 } & \text { MW } & 268 & 224 \\ \text { 熱供給能力 } & \text { Gcal } / \mathrm{H} & 40 & 220\end{array}$

の組み合せ可変の計画である.

（2）ごみ・污泥混焼発電所（北部発電所内）

前記のごとく，廃棄物は毎日処理せねばならず，電 力の需要変動負荷に左右されてでみ焼却炉として北部 発電所内に 1981 年末を目標に建設予定のものである. 詳細は別項に記すが，化石燃料とは混焼せず，下水污 泥との混焼を行うもので主要目は次のとおりである.

\begin{tabular}{|c|c|c|}
\hline 焼却炉数 & 2 基 & \\
\hline 焼却能力 & $480 \mathrm{~T} / \mathrm{D}$ & マルチン型 \\
\hline （１炉当たり）污泥 & $288 \mathrm{~T} / \mathrm{D}$ & 気流乾燥型 \\
\hline 発電出力 & $26 \mathrm{MW}$ & \\
\hline 熱供給能力 & $60 \mathrm{Gcal} / \mathrm{H}$ & \\
\hline 蒸気压力 & 41 ata & \\
\hline 蒸気温度 & $400{ }^{\circ} \mathrm{C}$ & \\
\hline ごみ低位発熱量 & $2,500 \mathrm{kcal} / \mathrm{kg}$ & \\
\hline 泥含水率 & $75 \%$ & \\
\hline
\end{tabular}

\section{1.4 熱供給の状況}

ミュンヘン市に抽熱供給は, 西独では最大規模の もので, 1976 年現在で, 供給家屋数 4,800戸, 熱供給 量は $1,400 \mathrm{Gcal} / \mathrm{H}$ に達しており，その年間伸び率は 10\%強である.乙の発達状況を図- 7 亿示すが, 前記の ごとく, 発電とごみ焼却の功妙な組み合わせにより比 較的市内の中心部にてれらの熱併給プラントを設置し ている.

熱供給の方法は, 歴史的な経過もあって, $1 \sim 3 \mathrm{a}$ ta の蒸気も使用しているが, 新設地区では $120 \sim 180{ }^{\circ} \mathrm{C}$ の高温水を供給するシステムを採用している.

熱供給源は, 表 1 にに示したように,でみ混焼熱併給 発電所, 熱供給発電所 (含ガスタービン発電所), 専 用熱供給所などによっている.

\section{1.5 使用燃料の状況}

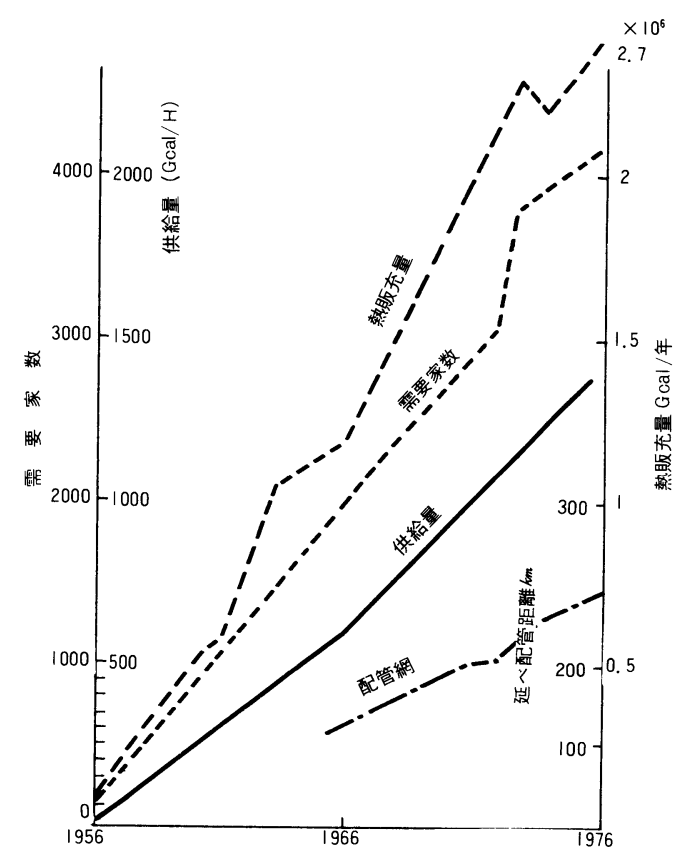

図-7 熱供給の発達状況

各発電所における使用燃料の熱量ベースの推移は, 時代と共に図- 8 亿示すように変化している.本来, 西 独においては, 石炭による発電が主流を占めていたが, 最近は石炭が減少し，ソ連を含む東欧諸国よりパイプ ライン輸送による天然ガスの比重が増加している. 重 油の使用割合は少なく，でみもそれほよ゙大きな割合で はないが，10\%程度の化石燃料の節減に寄与してる. 表 2 亿各発電所の使用燃料の組み合わせ状況を示す.

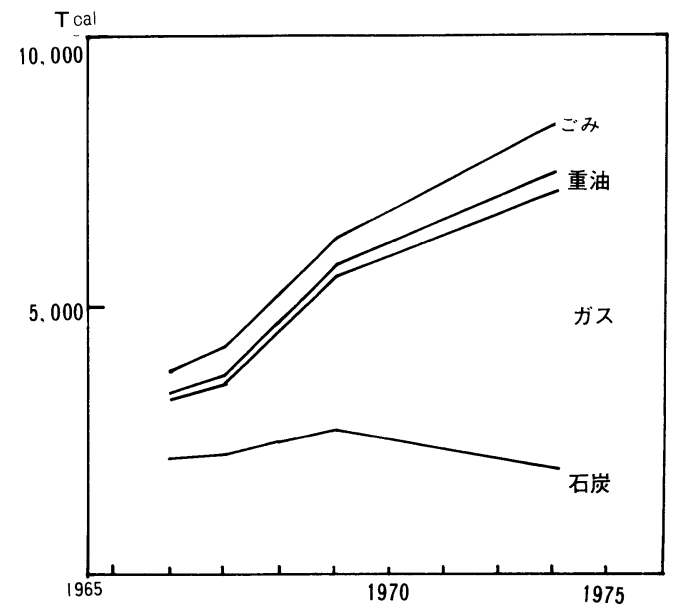

図-8 使用燃料の推移 
表 2 各発電所使用燃料状況

\begin{tabular}{|c|c|c|c|c|}
\hline 型式別施設 燃 料 & ガス & 石炭 & 重油 & ごみ \\
\hline $\begin{array}{ll}\text { ごみ混焼火力 } & \text { 北部 } \\
& \text { 南部 } \\
\text { 燃料専焼火力 } & \\
\text { ガスタービン } & \end{array}$ & 0 & 0 & $\begin{array}{c}(\bigcirc) \\
\bigcirc \\
0\end{array}$ & $\begin{array}{l}0 \\
0\end{array}$ \\
\hline
\end{tabular}

\section{2 ミュンヘンのごみの質と量}

\subsection{1 ごみの質}

ミュンヘンのごみの発熱量の変化を図- 9 亿示す. 図 中，横軸は月を示しているが，かって欧州でよくいわ， れた季節变化が日本と逆で, 夏季が高く, 冬季が低く なるという事はいい切れないように思われる。 乙の原 因は，地域暖房の普及と火力発電所でも見られる石炭 燃料減少が一般家庭に屯影響し，冬季化打り万家庭用 石炭暖房減少のため, 灰分が低下したためと思われる。

一方, 年毎のごみの発熱量は図中の平均值に見られ るごとく僅かながら上昇しており，2,200～2,300 $\mathrm{kcal} / \mathrm{kg}$ を示している. また, でみの比重については入 手資料のでみ発生量経年変化図から推算した結果, 最 近は 0.35 の状態が続いている. 日本のごみ発熱量と比 重の関係とは若干異なる傾向を示し，発熱量の高い割 合には大きい比重となっている，もっとも容積計測の 方法が不明であるので疑問も残るが, 経年的な比重変 化の傾向は参考にしてよいと思执る.

\subsection{2 ごみの量}

でみの発生量を図-10でみると，乙の15 年間で年間 200,000 Tから 500,000 Tと約倍増し 1370 T/日に相 当する.ちなみにミュンヘンの人口は， $1,200,000$ 人之 いわれるから $1 \mathrm{~kg} /$ 人・日強の排出量と想定される.さ

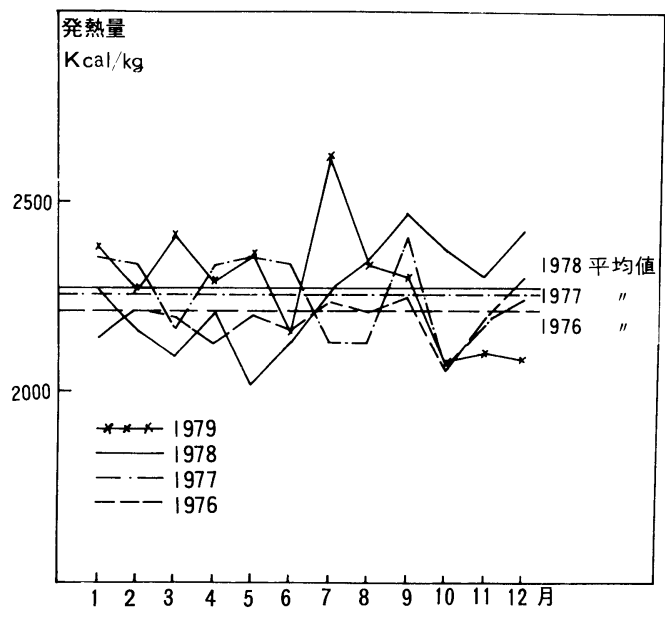

図-9 ごみの発熱量推移

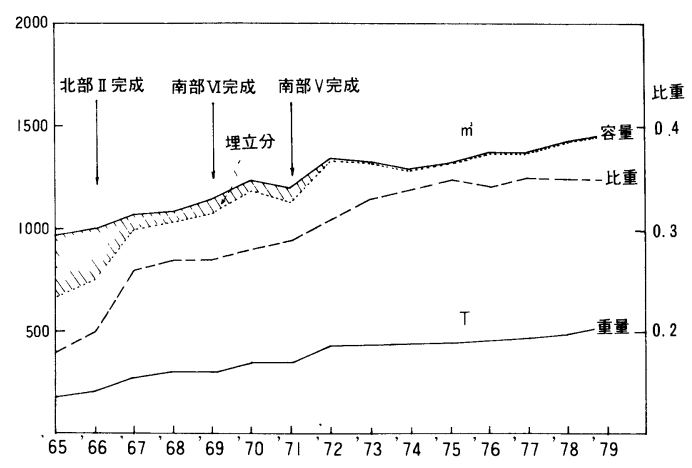

図-10ミュンヘン甫ごみ発生量と比重の推移

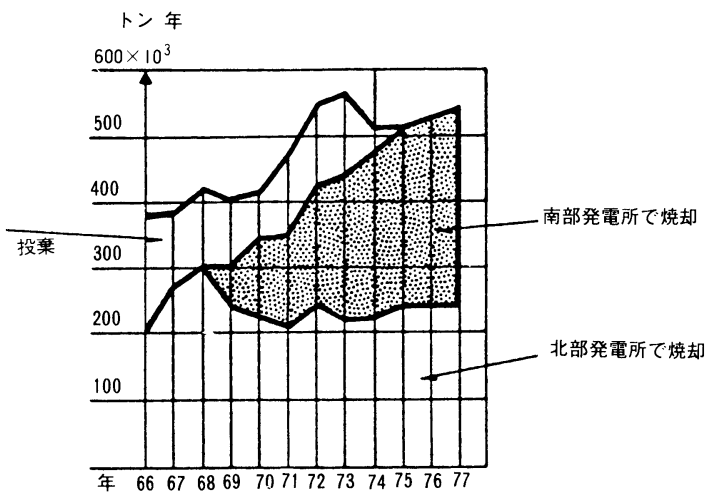

図-11 ごみ処理の推移

らに本図でわかることは1965 年頃迄は約30\%を埋立 に頼っていたわけで，1966 年:の北部 II，1969 年:の南 部 IV, 1971 年南部V 完成により, ほぼ全量焼却になっ たと思われる。

別の資料図，図-11ででみ処理の終年变化を見ると， 図-10の統計と若干の相異があるが, 埋立之南部, 北部 のでみ焼却の状況がよくわかる。

なお，北部，南部でみ焼却量の月別，年別変化によ れば，各年共一般的傾向として，2月，8月減少傾 向を示し，春，秋に増加傾向を示しているが，乙の要 因は調查未了である。

今後のでみの発生量増加予測については, 増加率は 漸次低減傾向を示すものと市は考えている模様である が，乙の原因についても調査未了である.

\section{3 ミュヘンのごみ焼却システム}

\subsection{1ごみ処理の歴史的経過}

前記のでとくミュンヘンのでみ処理は市の電力会社で 委託焼却されているが，以下にその共通的な概要を述 べ，別項に各発電所毎の特徵をプラントのシステムを 
中心に記すとととする.

ミュンヘンのでみ処理を歴史的に眺めると, 第 2 次世 界大戦中およびその数年後は市の北部に設置されたり サイクリングプラントにでみを集め, 利用できるむの は選別回収し市場に売られていた.しかし1950年代初 めから, これら回収物が急激に売られなくなり, この サイクリングプラントは閉鎖され，乙の北部地区に単 に埋立処分されるようになってしまった。てのため火 災が発生したり, 不衛生であることが問題化し, 市は その解决策の検討を各種の角度から開始した結果, ご みからのエネルギー回収之, 既石炭火力の SOx 低減
あ計れることからごみ焼却, 発電, 地域暖房を結合し たプラントを市の北部と南部に建設する事に決定した とのことである.

最初に作られたプラントは, 北部工場のブロック I であり 1964 年から操業に入り,ての実績と経験に基づ いて順次改良されながら北部ブロック II，南部ブロッ ク IV 抢よびVが建設されていったが，その主要目を表 3 亿示す.

\section{3. 2 ごみ焼却システムの共通的特徽}

てれらの焼却炉はいずれす現行の日本の焼却炬シス テムと比較して基本理念の出発点に打いて大きな差異

表 3 ごみ混焼熱併給発電所主要目表

\begin{tabular}{|c|c|c|c|c|c|c|c|c|}
\hline 番号 & プラント名 & 単位 & 北 部 I & 北 部 II & 南 部 IV & 南部 V & 北 部 III & 合 計 \\
\hline 1 & 操 業 年 & & 1964 年 6 月 & 1966 年 5 月 & 1969 年 4 月 & 1971 年 7 月 & 1881 年 12 月 & \\
\hline 2 & ユ ニ ッ 卜 数 & & 2 & 1 & 1 & 1 & 2 & 7 \\
\hline 3 & $\begin{array}{l}\text { 焼 却 容 量 } \\
(\text { ユニット当たり) }\end{array}$ & T/日 & 600 & 960 & 960 & 960 & 480 & \\
\hline 4 & 全 焼 却 容量 & T/日 & 1,200 & 960 & 960 & 960 & 960 & 5,040 \\
\hline 5 & ごみ低位発熱量 & $\mathrm{kcal} / \mathrm{kg}$ & $900 \sim 1,800$ & $900 \sim 2,000$ & $900 \sim 2,000$ & $900 \sim$ & 2,500 & \\
\hline 6 & 蒸 気 圧 (SHO $^{\text {力 }}$ & ata & 181 & 181 & 181 & 181 & 41 & \\
\hline 7 & \begin{tabular}{|cc} 
蒸 気 温 ( 度 \\
(SHO)
\end{tabular} & ${ }^{\circ} \mathrm{C}$ & 540 & 540 & 540 & 540 & 400 & \\
\hline 8 & 再 熱 压 $\begin{array}{c}\text { 力 } \\
\text { (RHO) }\end{array}$ & ata & 35 & 48 & 48 & 48 & $?$ & \\
\hline 9 & \begin{tabular}{|lll} 
再 & 熱 $\quad$ 度 \\
& (RHO)
\end{tabular} & ${ }^{\circ} \mathrm{C}$ & 540 & 540 & 540 & 540 & $?$ & \\
\hline 10 & 給 水 温 (ECO) & ${ }^{\circ} \mathrm{C}$ & 253 & 266 & 260 & 260 & $?$ & \\
\hline 11 & 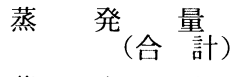 & $\mathrm{T} / \mathrm{H}$ & $2 \times 100$ & 365 & 365 & 365 & $2 \times 58$ & 1,411 \\
\hline 12 & $\begin{array}{ll}\text { 蒸 発 (ごみ量 } \\
\end{array}$ & $\mathrm{T} / \mathrm{H}$ & $2 \times 20$ & 73 & 73 & 73 & $2 \times 58$ & 373 \\
\hline 13 & $\begin{array}{l}\text { 蒸 発 量 } \\
\text { (燃料分) }\end{array}$ & $\mathrm{T} / \mathrm{H}$ & $2 \times 80$ & 292 & 292 & 292 & 0 & 1,036 \\
\hline 14 & ごみ 混 焼 率 & $\%$ & 40 & 20 & 20 & 20 & 100 & \\
\hline 15 & $\begin{array}{r}\text { 実 際 混 焼 率 } \\
\text { (3 年間) }\end{array}$ & & 20 & 18 & 12 & 12 & - & \\
\hline 16 & 主＼cjkstart燃＼cjkstart量 & & 石炭 & 石炭 & 天然ガス & $\begin{array}{c}\text { 天然ガス, } \\
\text { 重油 }\end{array}$ & - & \\
\hline 17 & 他廃棄物 混焼 & & - & - & - & - & 污泥 & \\
\hline 18 & 発電気出力 & MW & 68 & 124 & 124 & 124 & 26 & 454 \\
\hline 19 & 熱供給能力 & Gcal/H & 80 & 130 & $130^{\circ}$ & 130 & 60 & 490 \\
\hline
\end{tabular}


があるが，それらの特徴は次のとおりである.

（1）発電, 地域熱供給とでみ処理を複合化したこと.

(2) 発電, 熱供給をべースにし，でみを助燃料的にと らえて，プラントシステムの基本諸元が設計されてい るとと.

(3)したがって汽圧, 汽温の設定は高温, 高圧であり, ごみ処理容量もきわめて大きいてと.

(4) プラントの主燃料はドイッの国状から，石炭，天 然ガスをベースに計画されていること.

なよ゙である。

なお，表 3 には比較のために, 1981 年12 月完成予定 の他の燃料と混焼せず, 污泥のみ混焼する型式の新廃 棄物専焼焼却炉の計画諸元も併記した。

本表について以下若干の考察を試みてみたい。

コラムI の操業開始について見ると1964 年に北部ブ ロック I の 1 炉 $600 \mathrm{~T} /$ 日の大型の屯のを 2 基設置し, $2 \sim 3$ 年のピッチで遂時 $960 \mathrm{~T} /$ 日クラスのものを増設 した結果, 図-110ごとく現在 $100 \%$ 焼却を達成して いる.

コラム 5 の計画ごみ発熱量は $800 〜 1800 \mathrm{kcal} / \mathrm{kg}$ ら $900 \sim 2000 \mathrm{kcal} / \mathrm{kg}$ と上昇し, 建設予定の北部ブ ロック III では $2,500 \mathrm{kcal} / \mathrm{kg}$ 亿達している.

コラム 6 10のボイラの蒸気条件は前記のでとく発 電所プラント効率の上昇を狙って, 通常の発電所なみ の 181 ata $535{ }^{\circ} \mathrm{C}$ を選定, 再熱器付貫流ボイラとし, 発 電機タービンは多段抽気の河水冷却真空復水夕ービン を採用している．乙れらの各段からのタービン抽気は 地域暖房用温水の給水加熱器に利用すると同時に, プ
ラントの熱効率の上昇を考えてボイラ給水ラインの給 水加熱に利用して給水温度を $260{ }^{\circ} \mathrm{C}$ 程度迄加熱して いる.

コラム11〜13の蒸発量はコラム14の各プラント毎の ごみの混焼率とコラム16の混焼主燃料とも関係がある が, 北部は石炭, 南部は天然ガスを主燃料とし, ごみ はむしろ発電所に対する補助燃料であって，でみの蒸 気発生に対する寄与率は北部ブロック I が40\%, 他は 20\%である。なお，過去 3 年間における実際の運転実 績に基づくごみの蒸気発生寄与率をコラム15亿示す.

\subsection{3 ごみ焼却炉とボイラ型式の推移}

表 3 亿示す各ごみ焼却炉ボイラの形式については 北部ブロック I の経験と, 建設時点のニーズによって 順次改良之設計変更が行われたが,そのモデル図を図12に示す. いずれも焼却炉のストーカはマルチン型逆 送式ストーカを用い，ボイラは強制貫流型である．以 下各ブロック毎にその特幑の概要と計画の経過を記す.

(1) 北部ブロック II

ミュンヘンに括いて最初にでみ混焼を計画するに当 たっては, 電力需要の急激な増加に対処し, なおかつ ごみ混焼を考えたため, ブロック I に比較し, 発電能 力 $112 \mathrm{MW}$, ボイラ蒸発量 $540 \mathrm{~T} / \mathrm{H}$ と大型化し, ごみ 混焼率を40\%より20\%に低下させでみ焼却量を960 T /日に押えた計画になっている。乙の結果, 炉の形式は 下部にストーカを設置する一炉形式としたが，ての一 炉形式にするてとによってでみから発生しやすい不完 全燃焼ガスを微紛炭バーナ燃焼によって二次燃焼させ ることや，建設費の低減も計れることも併せて検討さ

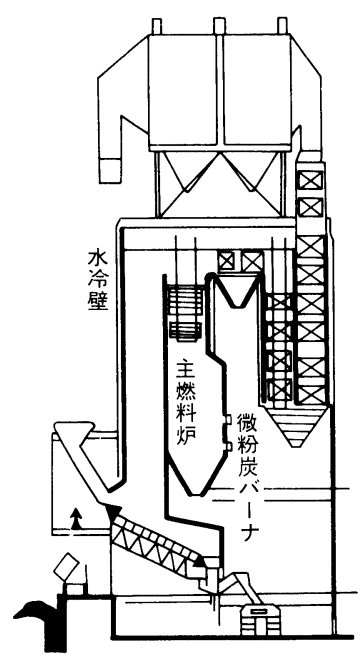

ミュンヘン北 I A + I B

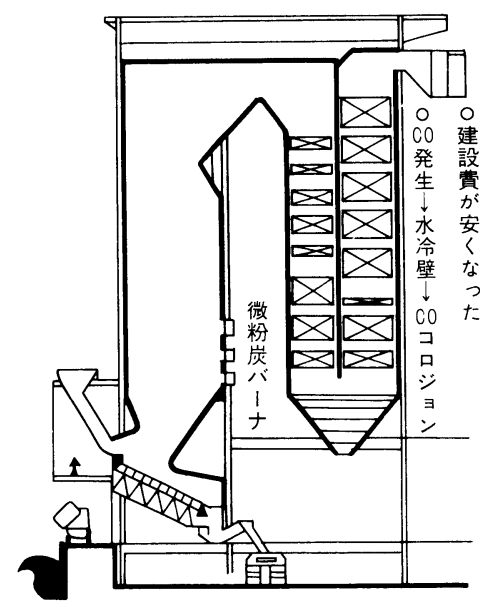

ミュンヘン北 11

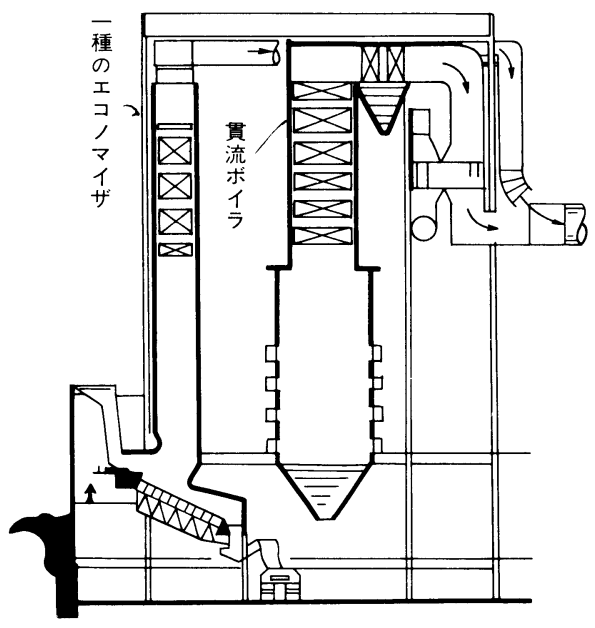

ミュンヘン南 $I V+V$

図-12 各ブロックごみ焼却炉ボイラ形式 
れて決定されたといわれている.

(2) 南部ブロック IV, V

北部ブロック II 引引続き， 1969 年， 1971 年に建設 されだものであるが, 両者とも形式は全く同一である. 発電能力 $124 \mathrm{MW}$ を除きボイラ蒸発量 $540 \mathrm{~T} / \mathrm{H}$, ごみ 焼却量 960 T/日は変わらないが, 炉の形式は全て設計 変更が行われた。 その詳細は別項に記すが，でみ焼却 炉と主燃料の炉を完全に別置すると同時に，でみ焼却 炉には通常は主燃料炉のボイラの節炭器として機能し, 主燃料炉停止時には, この圧温水をフラッシュさせ, 地域暖房の加熱蒸気源として利用させる特殊な形式の あのを採用している. 又主燃料ボイラの排ガスダクト には空気予熱器を設置し熱回収して排ガス温度を下げ, 焼却炉の節炭器出口の排ガスと結合させるので独立型 火炉を 2 個設置した形式のプラントともいえる.

(3) ごみ発電による熱回収状況

これら 2 発電所 4 ブロックの 1976 年度の操業実績 は, ごみ焼却量 465,865 厂であり，また，廃棄物から 得られた発電量は $245,070 \mathrm{MWH}$ である. この電力量 は家庭, 交通, 公共施設の消費電力の $9.2 \%$ だあ, 家庭消費電力のみで見ると $18 \%$ に相当する. また, 地 域暖房のごみ焼却熱の寄与率は $3 \%$ に当たる。乙れら 廃棄物の焼却による熱回収の総量は, 石油換算 65,300 $\mathrm{m}^{3}$ となり，住民 1 人当たりでは $50 \ell /$ 年にも達してい て，でみの熱回収量の如何に大きいかを理解できるで あろう．この原因は，日本ごみ焼却発電プラントと異な り, 発電所として汽圧汽温を上げ, 給水系統の熱回収 を計り, 河水冷却によるタービン排気压力を下げてプ ラント効率を上昇しているためであることは言を待た ない。

\section{4 北部ごみ混焼発電所}

\subsection{1 プラント全体概要}

本発電所は, ミュンヘンにおける最初のでみ混焼火力 発電所で, ごみの収集輸送距離の経済性を考慮して市 の中心部より $7 \mathrm{~km}$ という比較的近い所に建設されたも のである.プラントは前述のごとく $68 \mathrm{MW}$ のブロック I 発電設備之, $112 \mathrm{MW}$ のブロック II の発電設備より 構成されている.

ごみ焼却炉のストーカは, 油圧駆動の往復動式逆転 型ストーカで, でみを擋拌燃焼して灰押出機により水 分を切って灰ピットに排出されるが，途中で磁選機で 金属を回収する.乙の量はでみの $2 \sim 3 \%$ プレスで 60〜70 kg程度に圧縮し市場に売却される.

\subsection{2 ブロック I}

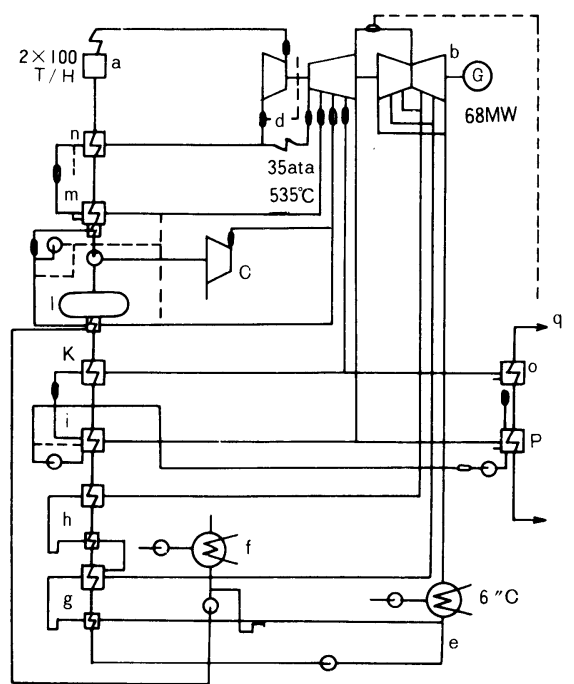

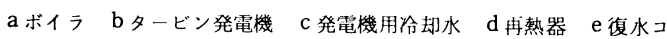
ンデンサ $\mathrm{f}$ 給水ポンプコンデンサ冷却水 $\mathrm{g}$ 真空給水加熱器 $\mathrm{h} 1$ 次 低王給水加熱器 i 2 次低圧給水加熱器 k 3 次低圧給水加熱器 1 脱 気器 $\mathrm{m} 1$ 次高压給水加熱器 $\mathrm{n} 2$ 次高王給水加熱器 $\mathrm{o}$ 地域暖房用熱 交換器 $\mathrm{p}$ 地域暖房用熱交換器 $\mathrm{q}$ 地域暖斿負荷

図-13 給水・蒸気系統闵

図-13は, ブロック I の蒸気ならびに給水の系統図 であるが, $100 \mathrm{~T} / \mathrm{H}$ ボイラ 2 系統と68MW 発電タービ ン 1 系統の結合状況を示している. ボイラ $\mathrm{a}$ を出た蒸 気は高圧タービンに送られ，その排気は再びボイラに 返されて再熱器 $\mathrm{d}$ により $35 \mathrm{ata}, 540^{\circ} \mathrm{C}$ 再熱され, 中 压タービンを経て復水タービンに至り, e のコンデン サーで復水される. 各夕ービンの抽気は, それぞれ給 水ライン中に設置された真空給水加熱器 $g, 3$ 段の低 圧給水加熱器 $h, i, k$, 脱気器 1,2 段の高圧給水 加熱器 $\mathrm{m}, \mathrm{n}$ に送気され給水を $253^{\circ} \mathrm{C}$ 迄加熱する構成 となっている. またての抽気の一部は蒸気駆動の給水 ポンプcにも使用される上同時に, 地域暖房用の温水 加熱器 $\mathrm{p}$, $\mathrm{o}$ にも利用されている.

これらの設置されたプラントの断面図を図-14亿 示す.

\section{4.3 ブロック II}

ブロック II はブロック I 完成後, 急激な電力需要の 増加に対処するために建設されたもので，出力を 112 MW に設定し， 365 T/Hの大型ボイラを選定したが， でみ焼却量とのバランスから計算するとブロック I の 混焼率40\%は無理で20\%に変更した経過がある. しか しながら，それであ，でみ焼却量は $960 \mathrm{~T} /$ 日と大型と なったが，混焼率の低いこと，建設費を低減させるこ と，でみの不完全燃焼を微粉炭燃焼で補うことなよ゙の 


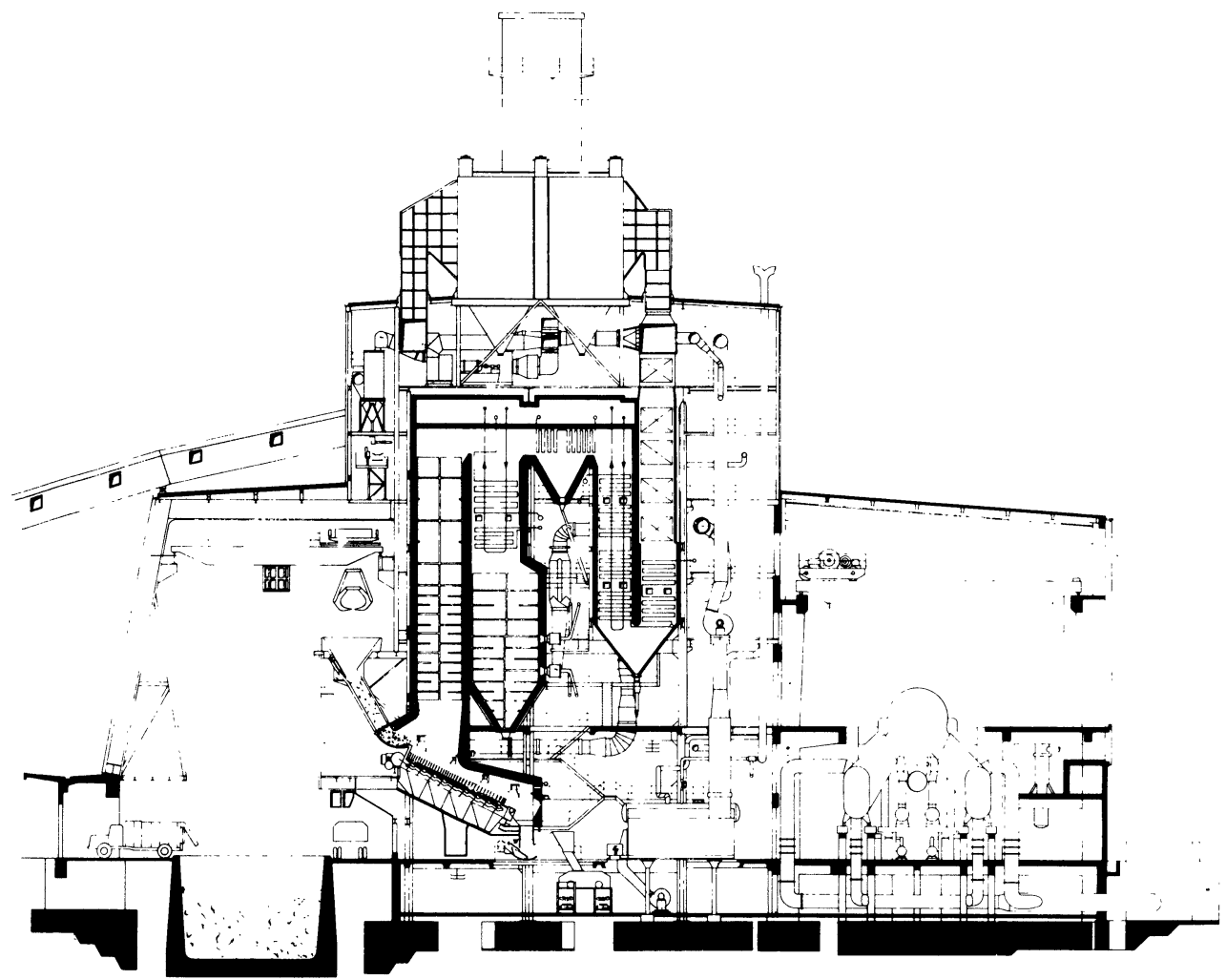

図-14 ブロック I 断面図

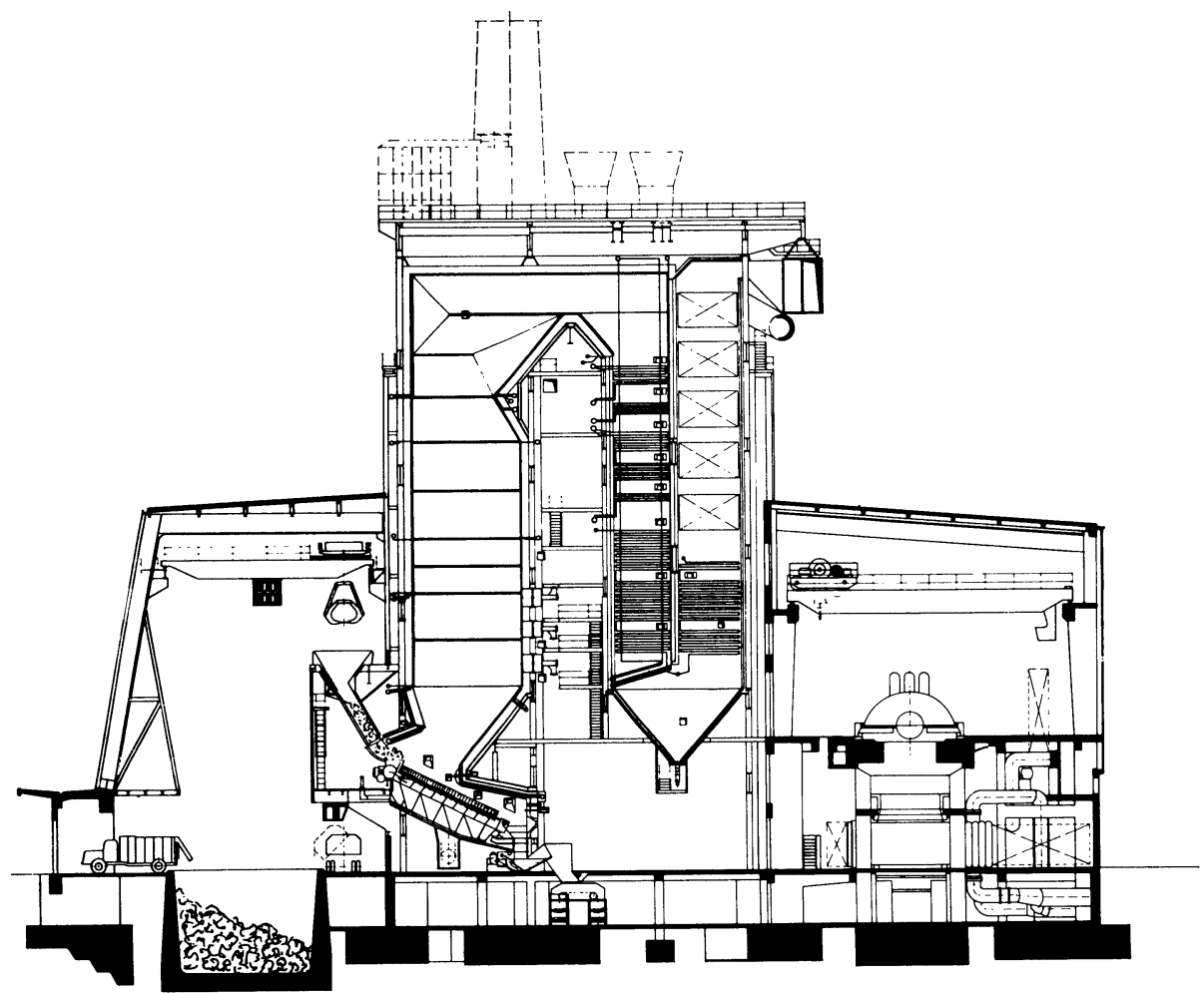

図-15 ブロック II 断面図 
表 4 北部 II の運転実積

\begin{tabular}{|c|c|c|c|c|c|}
\hline 年 & 度 & 位 & 1974 & 1975 & 1976 \\
\hline 収 & 人 & 人 & 442,000 & 457,200 & 525,800 \\
\hline ご み 焼 & 却 & $M G / Y$ & 142,260 & 138,465 & 164,960 \\
\hline \multirow{3}{*}{$\begin{array}{c}\text { 回収エネルギー量 } \\
\left(\begin{array}{l}\text { 除プラント内 } \\
\text { 消費エネルギー }\end{array}\right)\end{array}$} & 電 & $\mathrm{MW} \mathrm{H} / \mathrm{Y}$ & 80,500 & 79,250 & 94,160 \\
\hline & 地域暖房 & $\mathrm{GJ} / \mathrm{Y}$ & 20,265 & 23,030 & 35,490 \\
\hline & 全エネルギー & $\mathrm{G} \mathrm{J} / \mathrm{Y}$ & 742,065 & 743,470 & 918,510 \\
\hline \multirow{2}{*}{$\begin{array}{l}\text { 回収エネルギー } \\
\text { の軽油換算値 }\end{array}$} & 年当たり & $\mathrm{M}^{3} / \mathrm{Y}$ & 22,380 & 22,420 & 27,700 \\
\hline & 1 人当たり & $\ell /$ 人.年 & 50.6 & 49.0 & 52.7 \\
\hline
\end{tabular}

理由から，図-15に示すでとく，1 炬ででみと石炭燃焼 炉を結合した設計となったとのととである．蒸気一給 水ラインについてはほぼブロック I と同様であり, 再 熱器のみ 47.9 ata, $540^{\circ} \mathrm{C}$, ボイラ給水温度 $266^{\circ} \mathrm{C}$ と異 なっている.

煙突はミュンヘン空港の近くにあるため $80 \mathrm{~m}$ と低い 設計となっているが, 電気集じん器は $99.75 \%$ の高い 効率のあのを設置している.

表 4 亿ブロック II におけるでみ焼却実績から回収電 力量と回収熱供給量を軽油節減に換算した結果を示す. これはミュンヘン全体の試算結果と合致し，1976 年で は 1 人年間約 $50 \ell$ の節減結果となっている.

\section{4.4 ブロック III}

ブロック IIIについては, ブロック I ， II に隣接して 建設予定で先にその設置理由を記したが，他のブロッ クと較べると発電機出力を低く設定して打り, 汽圧 41 ata，汽温 $400^{\circ} \mathrm{C}$ と押えた日本型のでみ発電焼却炉と いえる.ただし，污泥との混焼は他のドイッの諸都市 であ実施中であるが，主ブロックではでみ $480 \mathrm{~T} /$ 日 に対して288 T/日と非常に大型のものであり, 完成が 注目される. ちなみに污泥の持込水分は $75 \%$ といわれ ている.な报，公害対策としては電気集じん器出口で $100 \mathrm{mg} / \mathrm{Nm}^{3}$ とし, $\mathrm{HCl} 100 \mathrm{mg} / \mathrm{Nm}^{3}, \mathrm{HF} 5 \mathrm{mg} / \mathrm{Nm}^{3}$ の ガス洗涤装置をミュンヘンとしては始めて設置する計 画との事である.

\section{5 南部ごみ混焼発電所}

\subsection{1 プラント全体概要}

南部発電所は市の中心部にあり, 1925 28 年に低圧 発電所として稼動していたイザールシュトラセ発電所 の跡地に建設されたもので，既設のブロック I， II， III の各 30,000 KW の中圧の熱併給発電所に隣接しで み焼却混焼熱併給発電所ブロック $\mathrm{N}, \mathrm{V}$ として北部発 電所の型式に改良を加えて高圧型で設置されたもので ある.プラントの全体は, 巾 $51 \mathrm{~m}$ という細長い敷地に
建設したため, 配置に苦労が伴ったとのととである. ブロック I 〜 III と, 地暖用熱供給所の燃料は石炭で, ごみ焼却火力の主燃料は天然ガスと石油が用いられる ようになっている.従って道路をへだてた南側に 10,000 mの油タンク, 川に沿って北側から天然ガスのパイプ ラインが敷設され，それぞれ発電所に接続されている. でみはプラントの北側にある主道路よりでみピットに 搬入される.また，冷却水は，東側にあるイザール川 の支流から引込まれており，てれらの各ユーテリーを 受けて発電を行なっている．焼却灰はコンべヤで敷地 の南側に運ばれて磁選により金属を分離，西側の引込 線で直接鉄道で製鉄所に送られ，残灰は灰ヤードより トラックにて搬出される．煙突は $175 \mathrm{~m}$ で電気集じん 器は, $99.5 \%$ の効率である.

なお，ブロック I， II， IIIの中圧発電所は最近撤去 され，その跡地に先に記載したガスタービン熱併給発 電所を建設中で近く稼動に入る予定である.

図-16亿発電棟の断面図を, 図-17亿蒸気, 給水系統 図を示すが, 本プラントのでみ焼却量, 蒸発量, 蒸気 条件は総てブロック II と同一である.

\subsection{2 蒸気，給水系統の特徵}

本プラントは, 北部ブロック II とほぼ同一容量では あるが，市の中心部にあり地域暖房のニーズが高いの で，ての点に工大を加えると共に，タービン定検中で 屯地域暖房とでみ焼却が問題なく効率よく稼動できる よう給水, 蒸気ラインと, ボイラの組み合わせに特徴 のあるシステムを採用している．基本的な給水加熱シ ステムは図に示すように北部ブロック II とほほ同一で, ボイラ出口の蒸気を高圧タービンに送り, 再熱器で中 圧タービンを経て復水タービンに送気発電するが, 各 段抽気は給水加熱と地暖用熱交換器にうまく利用して いる.

北部ブロック II との大きな相違点は, 焼却炉用の貫 流型水冷壁を通常主ボイラの節炭器としてシリーズに 


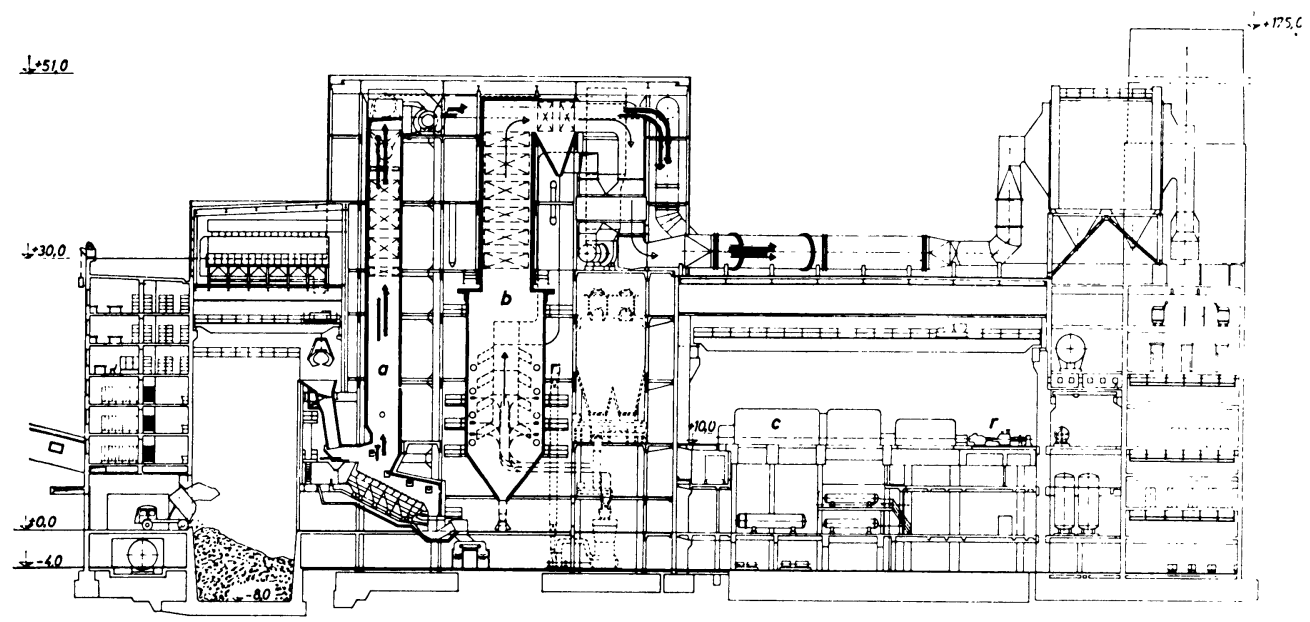

図-16 発電所断面図

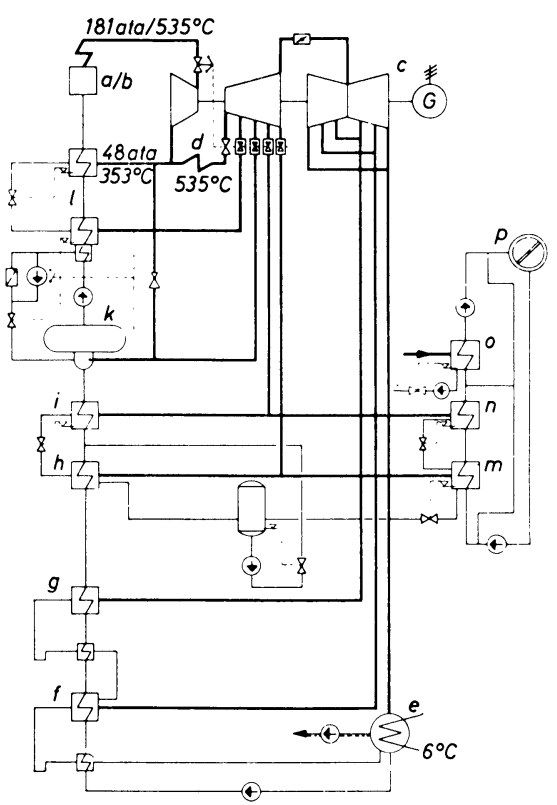

図-17 給水・蒸気系統図

運転することである。しかし，燃焼系統は全くそれぞ れ別の火炬で形成され，主ボイラの燃焼ガスはユング ストローム型空気予熱器で $120^{\circ} \mathrm{C}$ 程度迄熱回収し, で み焼却ガスは節炭器であるため $300^{\circ} \mathrm{C}$ 程度迄熱回収し た後合流する.

てのような構造のため，建設費が高くなるが，でみ 焼却炉のボイラが停止中でもバイパスラインを使って 主ボイラに直接給水し, 全出力の発電ができるように なっている．また，主ボイラが何かの理由で停止した 時は, でみ焼却ボイラを 110 ata 迄下げて節炭器とし てそのまま使って運転し，フラシュタンクで 8 ata の
蒸気を発生し，地暖用温水加熱器に蒸気を供給できる ようになっている，てのためどちらの炬が修理, 故障, 定検であっても機能することができるわけであり，ま た，焼却炉は節炭器であるため，管壁温度が低くなり 腐蝕防止にも大きな利点を有している。

給水ポンプは発電タービンと直結のもの之, モー夕 駆動のあのとを設備してある.

\section{6 運営経費}

廃棄物の処理は市自身の仕事であるが, 発電, 熱供 給などは市の独立企業体が行っている．したがって 廃棄物がエネルギーを有しているから燃料代として市 に支払うべきだが，焼却のための経費を受け取る必要 あある．乙の考え方に基づく 1978 年の計算結果は次 のとおりである.

(1) でみトン当たり焼却に要する費用

$\begin{array}{lrl}\text { 固定費 } & 15.2 & \mathrm{DM} \\ \text { 税 金 } & 2.3 & \mathrm{DM} \\ \text { 人件費 } & 9.4 & \mathrm{DM} \text { (100 人) } \\ \text { 電気代 } & 5.3 & \mathrm{DM} \\ \text { 保守費 } & 9.0 & \mathrm{DM} \\ \text { その他 } & 14.7 & \mathrm{DM} \text { (一般管理費) } \\ \text { 合 計 } & 55.9 & \mathrm{DM}\end{array}$

(2) ごみトン当たりの収入

$\begin{array}{lrr}\text { 蒸気収入 } & 33.2 & \mathrm{DM} \\ \text { 廃鉄収入 } & 0.7 & \mathrm{DM} \\ \text { 合 計 } & 33.9 & \mathrm{DM}\end{array}$

(3) ごみトン当たり必要費用 $55.9-33.9=22.5 \mathrm{DM}$

なお，乙の計算に使用した各種燃料の発電単価は次 のと抢りである. 
1978 年 1980 年

$\begin{array}{llll}\text { 石炭 } & \mathrm{DM} / \mathrm{MWH} & 16.0 & 23.0 \\ \text { ガス } & \mathrm{DM} / \mathrm{MWH} & 18.0 & 27.8 \\ \text { 重油 } & \mathrm{DM} / \mathrm{MWH} & 18.0 & 35.0 \\ \text { 軽油 } & \mathrm{DM} / \mathrm{MWH} & 25.0 & 50.0\end{array}$

重油, 軽油は非常に上昇が見られるのは当然として, 石炭は石炭助成策が採用されているので低く押えるて とができている模様である.

図-18は，入手資料によるこれら運営経費の経年変 化図である．検討のために同図に，でみ処理量(D)プ ロットし, 年間総経費(Aより, でみから得られる収入 (B)を差引いた(A)一Bを計算, (A)- B / (D)を算出すると, ほぼ表示の全額之合致する。また，前項にかかげた， 1978 年のでみ処理経費とも一致するので, 経年変化を 知る上で参考となる。

\section{7 あとがき}

今回の調査は焼却炉単体でなく, ごみ焼却, 発電, 地 域暖房などそのシステムの構成と運営形態を中心に 行ったのであり，一応の成果を得られたものと判断す るが，以下に所見をまとめてみたい。

(1) ミュンヘンでは, 電力の需要と地域暖房のニーズ に応え，かつでみ処理の必要性を完全に一体化し，日 本では考えられない比較的都心に発電所ベースのでみ 混焼熱併給発電所を建設した. したがって, 総てのプ

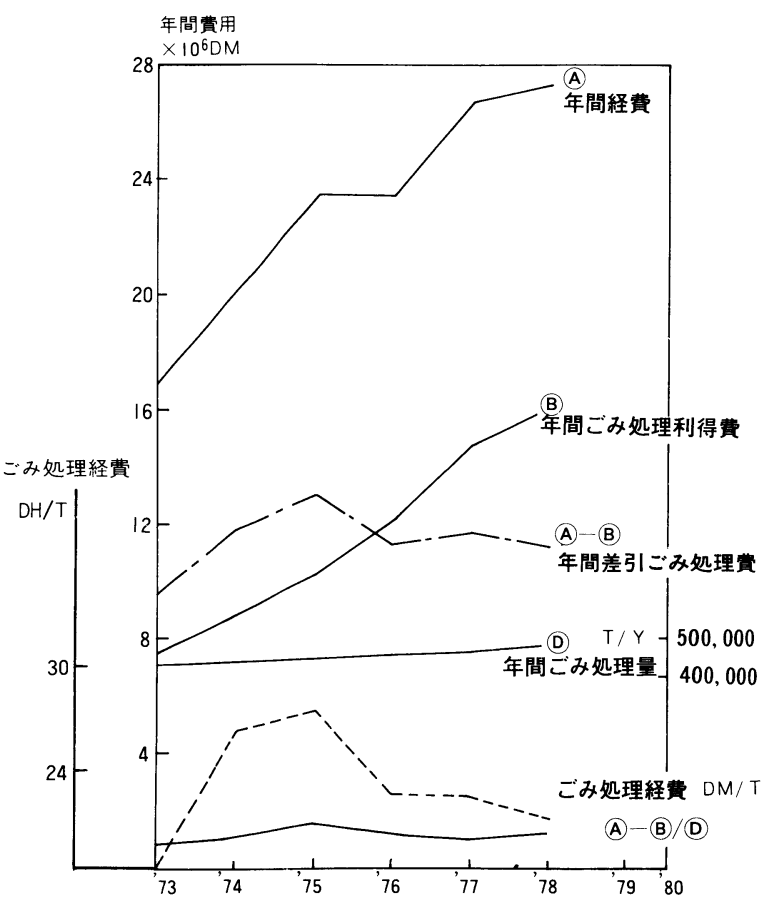

図-18 ごみ処理経費経年変化
ラントの汽圧汽温は高く, ごみ処理量も大型で熱回収 率も非常に有効である.

(2) 各ブロックの歴史的経過を見ると, それなりの社 会的ニーズに応えてプラントシステムの改良を巧妙に 行っており, 特に北部ブロック III の污泥混焼システム の採用は注目され完成が待たれる.

(3) 運営経費もその経過から合理的になっており, で みの処理経費が極めて廉価である. このととはシステ ムばかりでなく運営形態に拈いて日本と大きく異なっ ているてとに起因している.

以上ミュンヘンにおけるでみ処理形態の特徴を列記 したが，わが国においても，近時各方面で新システム の検討が活発になされるようになってきた。 よくいわ れるように, ごみ質, 立地条件, 公害問題など, 欧州 とは差があるのは事実であるが，資源問題から考える と真剣に実行に移さねばならない時がきつつあるよう に思われる。

今回の報告は入手資料，聴取事項を整理して見ると 未調查事項が残っていて悔まれる部分があるが，何ら かの機会に補完をしたいとも考え，また補完をしてい ただきたいとも思っている．そのための資料になれば 報告者の望外の喜びである.

資料

$$
\begin{array}{ll}
1 & \text { コミニィティ発電システム訪欧調査団 T. T. I. } \\
2 & \text { マルチン社各種資料 } \\
3 & \text { ミュンヘン電力会社人手資料 M. Steljle } \\
4 & \text { 南部発電所パンフレット } \\
5 & \text { 北部発電所パンフレット } \\
6 & \text { M. Andritjky, The Munich refuse incineration plant } \\
7 & \text { G. Stabenow, New incineration Munich } \\
8 & \text { 一般廃棄物, 下水污泥からのエネルギー回収調査報告書 } \\
& \text { 科学技術庁 資源調査会 }
\end{array}
$$

\section{4. ウィーン市ごみ焼却施設}

\section{1 ウィーン市のごみ焼却施設}

われわれ調查団が訪問したのは, ウィーン市の西部フ レッッアシュタイクにある処理能力 $600 \mathrm{~T} /$ 日（200 T/日 焼却炬 3 基）の都市でみ焼却施設である. 本施設は 1963 年完成亡, 極めて古い施設であるが，その後いく つかの改善を加えつつ現在も順調に稼動している.

ウィーン市には, 都市ごみ焼却施設が 2 か所, 産業 廃棄物総合処理施設が 1 か所ある. 都市ごみ焼却施設 は，今回訪問したフレッッアシュタイクの焼却施設の ほかに 1971 年に完成した $600 \mathrm{~T} /$ 日（300 T/日焼却炉 2 基）の焼却施設がある. また 産業廃棄物総合処理 
施設はこのほど完成し, 目下試運転中である.

\section{2 本焼却施設設置までの経緯}

\section{2.1 ごみ排出量の増大と焼却施設の必要性}

ウィーン市のでみ排出量は 1954 年には, 年間 55 万 $\mathrm{m}^{3}$ であったが，経済事情の好転にともなって急激に增加 し, 1959 年には 75 万 $\mathrm{m}^{3}, 1963$ 年には 110 万 $\mathrm{m}^{3}$ というぺー スで增加しつつあった。

同市では, 既に 1956 年以来都市でみのコンポスト 化プラントが運転され，それ自体としては有効に機能 していたが，同市でみの全収集量の $6 \%$ 程度を処理す るのが精一杯で, 增え続けるごみの処理には有効な手 段とはなりえなかった。 てのような事情から 1959 年に 到り，それ迄に同市がとりまとめていた焼却法の調查 研究の結果にもとずいて, 同市で最初の焼却施設を建 設するととが決定した。

\subsection{2 設置場所の選定}

本施設の設置場所として, 前述のフレッッアシュタ イクが選ばれたのは次の 2 つの理由によるあのである. すなわち，

(1) でみの運搬上，位置的に良好であったこと．

(2) でみ焼却炬により発生する蒸気の需要先として, ヴィルヘルミー亦総合病院, バルムガルトナー「精神 病院，甫立中央洗濯場，オクタリンガー・ブール，そ の他住宅施設など, 多くの熱需要家が既に周辺に存在 していたからである.

\subsection{3 機種の選定}

機種については, トラブル・フリーであるてと，そ して経済性ならびに低カロリーでみに対する焼却効率 の良さなどの優れた点が評価されて，スイスの VON ROLLシステムが採用された。

\section{3 本焼却施設の概要}

\section{3. 1 本焼却施設の主要目}

(1) 焼却能力 $600 \mathrm{~T} /$ 日

（200 $\mathrm{T} /$ 日 3 基）

(2) ボイラ

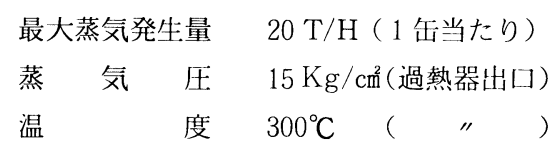

(3) タービン

$\begin{array}{lll}\text { 発電容量 } & 3.5 \mathrm{MW} \\ \text { 压 力 } & 15 \mathrm{Kg} \\ \text { 温 } & \text { 度 } & 280^{\circ} \mathrm{C}\end{array}$

(4) 完成年月 1963 年 12 月

(5) メーカー VON ROLL社（スイス）

\subsection{2 プロセスの説明}

(1) 焼却プロセス

ごみ収集車で運搬されてきた生でみは，予備選別す ることなくでみピットに投入される。燃焼に必要な空 気をピットから取っているため，ピット内は外気圧よ り低くなっているので, 門屝の開閉の際にばい塵や悪 臭が洩れないようになっている，また，施設全体とし てもすべてのプロセスが広範井にわたり自動化されて いるので，作業員がごみに直接接触するととはない。

グラブクレーンでホッパーに投入されたでみは, 乾 燥ストーカへ落下しそてで輻射熱により乾燥点火され た後, 次の燃焼ストーカで焼却される.乙の燃焼スト一 力の次に設けられているのが, いわゆる後燃焼装置（ガ シファイアー）である．ここでは15気压の高压のもと で，未燃力ーボンに直接蒸気を吹き込んで水性ガス反 応を行わせ，未燃分を有効に燃焼させるあので VON ROLL 式焼却炉の特徴の1つとされている.日本でも 大阪市（西淀）で採用されているが，本装置が高温高 圧下の運転のため維持管理がやや難しいととと, コス 卜的にも若干高くつくなどの理由からその後採用され ていない，後燃焼装置底部から掻き落された焼却灭は， 前段のストーカより落下してきたものと共に，韲った スラッジ状でコンベヤーにより焼却灵ピットへ運ばれ る.乙れらは, 生でみに対し体積で約 $1 / 10$, 重量では 約 $45 \%$ あ゙る。

\section{(2) 蒸気供給と発電}

各ボイラ・ユニットは蒸気压 $15 \mathrm{Kg} / \mathrm{cm}^{2}$, 温度 $300^{\circ} \mathrm{C}$, 蒸気発生量 $15 \mathrm{~T} / \mathrm{H}$ (最大 $20 \mathrm{~T} / \mathrm{H})$ で運転されてお り, ての発生蒸気は 2 本の導管によって約 $1 \mathrm{~km}$ 離れた 前述の各需要家に供給される.

本焼却施設には発電設備が付属して抢り, 主として 夏期の余剩蒸気を利用してて発電し, 幹線配電線へ送り 込んでいるが，夏以外の季節に扔いてもボイラ压と使 用蒸気圧との差を利用して, 時々発電しているとのて とで，年間の発電量合計は 200 万KWHにのぼる.

上記のことからもわかるように，本焼却施設は都市 ごみの焼却処理と周辺需要家倿対する蒸気供給を主要 目的としているので, 発電はその余剩蒸気を利用する など，どちらかといえば副次的なものとして扱われて いるのが特徴といえよう.

(3) 廃ガス対策

本焼却施設の集じん装置は，コットレルとマルチサ イクロンの併用という方式を採用しており，乙れによ り廃ガス中のばいじんは $200 \mathrm{mg} / \mathrm{Nm}^{3}$ 以下にまで浄化 
されて, $100 \mathrm{~m}$ の高さの煙突から放出される.

このコットレルとマルチサイクロンの組み合わせは, EP灰中の未燃カーボンブラックを光全に除去するために 組み合わせ設置されたもので，京都市（北）などにもこの 方式が採用されているが, 最近では廃ガス中の水蒸気 が多くなり，水分が高くなったので，コットレルのみ でも充分に除去できるとの理由から，マルチサイクロ ンは併用されなくなり，その意味からあ珍しい屯のの 1 つといえる.

また，本焼却施設では廃ガス中の $\mathrm{HCl}$ 除去のために， 1 年前より $\mathrm{CaO}$ 乾式吹込みを実施して抢り，乙れに よって煙突出口における $\mathrm{HCl}$ 濃度が従来 1, 000 1,500 $\mathrm{mg} / \mathrm{Nm}^{3}$ であったものを，現在は $150 \mathrm{mg} / \mathrm{Nm}^{3}$ にまで低 下させている。

\section{3. 3 リサイクリング}

本施設では，エネルギー回収のほかに有価物の回收 再利用屯はかっている. 先ず, 鉄分であるが，1968年に磁 選機，プレス等のリサイクリング設備が設置され，年間 2,200トンの鉄分が回収され， 1 コ約 $80 \mathrm{~kg}$ のブロック にプレスされてリンツの製鉄所に送られ，トン当たり 520 シリング（約 1 万円弱）で引きとられる.また, $\mathrm{EP}$ 灰は壁材，又は道路建設工事に打ける盛土，築提 あるいは埋立材として建設会社へ，トン当たり20シリ ング（約 400 円）で売られる。乙の值段は極めて安い が、 巳P皮がこのように一応值段がついて販売される のは，興味樑いことであった。

\section{3.4 運転開始以来の改良点}

本施設は, 1963 年稼動開始以来, 環境条件の変化之 永年の運転経験をべースとして, 各種改善をほよ゙こし てきた．その一部については，既に今までの説明の中 で述べたが，それ以外にも次のような改善がなされて きた。

（1）貴重な上水を節約するために，湿式除じん方式か ら乾式除じん方式に改造され，それによってでみトン 当たり水消費量が $75 \%$ 亿減少した。

（2）ボイラの起動および停止時の騒音レベルを低下さ せるために消音装置が装備された.

（3）ごみ受入量を正確に算定するため，ならびに合理 化抢よび労力軽減のために, 計量台を完全電子システ ムへと変換した。

（4）完全自動中和設備により，焼却灰処理廃水の水路 網への放流が無害であることが保証された。

\section{4 運営形態その他}

\section{4.1 運営形態とマネーフロー}

発生した蒸気の供給は，市の第48課が管轄し，他の 機関を通じずに直接需要家に送られる. その蒸気販売 代金は，それぞれ管轄する需要家別にわかれた部課， 例えば病院からの蒸気代金は病院を管轄している第44 課が回収し，その第44課が第48課に支払うという形式 をとる.一方, 電力は同市の電気・ガスを管轄するシュ タットヴェルケという部局に一度送られ，そてから需要 家へ送電される。あちろん代金むシュタットヴェルケ を通して回収されるわけである。

1979年度に掞ける本焼却施設の収支を, 同市経理担 当部門の報告でみると次のとおりである.

本焼却施設の代金収入 24,580 千シリング

(約442 百万円)

経費 31,709 チ・シリング

（内 訳）

(約 570 百万円)

$\begin{array}{lc}\text { 人 件 費 } & 16,594 \text { 千シリング } \\ \text { 補 修 費 } & 11,755 \quad " \\ \text { 償却費 その他経費 } & 3,360 \quad "\end{array}$

差 引 $\quad$ 引 7,129 千シリング

(約 128 百万円)

上記のとおり，収支決算は赤字となっているが，そ の理由の 1 つは市の病院が赤字で悩んでいるため, 本 来なら蒸気トン当たり 270 シリング (約 5,000 円) で売 るところをトン当たり 100 シリング（約 1,800 円）と $1 / 3$ 近くの值で売っていること，また人件費がかさむ ことなどがあげられる。ちなみに本施設の従業員は64人， 1 回 7 人, 6 シフトで操業している.

\section{4.2 蒸気および電力の供給単価}

前述の収入のベースとなる蒸気, 電力の供給単価は 次のと抢りである.

蒸 気 1 トン当たり 100 シリング

(約 1,800円)

（前項参照のこと）

電 力

（夏期） $1 \mathrm{KWH}$ 当たり 12 グロシェン

(約 2 円 16 鐵)

(冬期)

20 グロシェン

(約 3 円 60 鐵)

\subsection{3 ごみの総発生熱量と蒸気供給, 発電への配分}

本施設の処理能力は, 当初 $600 \mathrm{~T} /$ 日であったが, 最 近の焼却実績はほぼ 490〜500 T/日である. 1 トン のごみを焼却することにより得られる熱量は約 $0.8 \mathrm{G}$ cal であるので 1 日の総発生熱量は $480 \mathrm{Gcal}$ となる. 冬期は, この $480 \mathrm{Gcal}$ の熱量のほとんどすべてが蒸 
気供給にまわされるが，夏期は $150 \mathrm{Gcal}$ が蒸気供給 へ, 残り $330 \mathrm{Gcal}$ が発電にまわされる.

\section{5 あとがき}

ウイーン市でみ焼却施設を訪問調査するに当たって は，焼却炉，エネルギー回収設備に関する技術上の問 題むさることながら, その運営形態や操業の実態, 採 算性などを把握するてとも重要なポイントであった。 幸いにして, ウイーン市に抢けるでみ焼却ならびにエ ネルギー回収の運営形態や収支を把握するてとができ たか，採算については，特殊事情により病院に安く蒸 気を供給しているが故に，収支は一応赤字となってい たのは止むを得ない。

発電については本施設の場合，二次的な立場に置か れているので，今回視察した欧州各地の施設の中では 特殊な例といえるが, 病院をはじめとする熱需要家が 既に存在し，それらに対する熱供給老目的として需要 家群の中心没設置した焼却施設に求けるエネルギー回 収再利用の実態を知ることができ，有意義であった。

\section{資 料}

1. THE REFUSE-INCINERATION PLANT IN VIENNA BY SENATSRAT DIPL-ING. FRANZ FISCHER LEITER DER STADTREINIGUNG WIEN

2. VIENNA'S REFUSE INCINERATION PLANT

3. MULLVERBRENNUGSANLAGE AM FLÖTZERSTEIG

\section{5. パリ市都市廃棄物処理の状況}

\section{1 パリ市こみ処理事業の沿革}

現在は, フランス電力公社の都市廃棄物産業処理局 そ属している. (TREATMENT INDUSTRIEL

DER RESIDUS URBAINS T I R U)

パリ市のごみ処理業務は，1899 年にさかのぼる．当 初は, ENGRAIS COMPET 社に請負で, 収集之破砕 のみの処理であった. 工場はサントワン工場のみで あった。 その後, ロマンヴィル，イッシィームリノ工 場が設立され，1910 年イブリ一工場が完成した。

T I R Uは 1922 年に設立され，パリ市より委託されて でみ処理に当たるてとになった。

1933 年, T I R U はセーヌ県のでみを扱うように拡 大され, セー又県の管轄下に入った. 乙の時期に T I R U の現在の運営基礎が出来た.

1946 年, 法律改正によりフランス電力公社に移管さ れ, 電力公社がセーヌ県の代理者として管理すること になった. (TIR U d'ELECTRICITE DE FRANCE) 1964 年, セー又県が 4 つに分割され，セ一又県に
代ってパリ県が 1968 年より管轄し, 各県からの代表に より構成される12名の監視特別委員会が組織された。

1976 年から, 法律改正によりパリ市が T I R U 局を 管轄している.

\section{2 運営組織}

国家事業団

フランス電力局（国営）

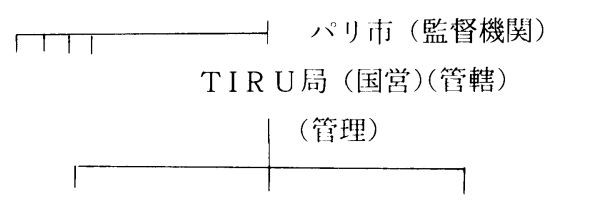

開発事業部管理会計部研 究 部

各処理工場

T I R U 局は, パリ市に事業の予備報告, 決算報告 を提出する。乙れにもとずいてパリ㻏は，周辺市町村 の負担額を計算し，その費用を計算する.

\section{3 運営状況}

TI R U は, パリ周辺に4つの処理工場をもつて いる。パリ沛以外の市町村は，契約の下に T IRUK 処理を委託计来る.

T I R U の処理する廃棄物量は，柋間約 1, 700, 000 トンであり，年間を通じてかなり変動する.

冬期ピーク 1 日 $6,000 \mathrm{~T} に も な り ，$

夏期には 1 日 $3,000 \mathrm{~T}$ 程度になる。

収集は, 午前中約 3 時間以内で行われ，冬期には， 1,500 台余りの収集車が稼動する。パリ市人口は約 2,300,000 人であり，TI R UK委託しているパリ市以 外の人口は，2,200,000人である（合計 4,500,000人).

でみの量は, パリ市で 1979 年に狲て, 約 1,000,000 トン, パリ市以外約 600,000 トン, 産廃 60,000トンで ある.

T I R U で処理する廃棄物は, フランス全体の人口 比で $10 \%$ ，都市廃棄物量比で $13 \%$ となる.

パリ市は，会計年度末に予算に応じて支払われてい た各市町村の委託料を T I R U の報告にもとずいて修 正し, 各市町村は直接, T I R U と支払い（または受 取り）の修正をする。

各市町村に割当てられる全体額は, T I R U の運営 経費から TIRU が得る売却益と個別に委託を受けた， 委託料を差引いたすのとなる.

表 5 にイブリー工場の収支を示した。

\subsection{TIRUの工場概要}


表 5 イブリー工場の収支

\begin{tabular}{|c|c|c|c|c|}
\hline & \multicolumn{3}{|c|}{1979 年 } & 1975 年b) \\
\hline 人 件 費 & $14.63 \mathrm{~F} / \mathrm{T}$ & \multicolumn{2}{|c|}{$(880 \mathrm{H} / \mathrm{T})$} & - \\
\hline 償却 ${ }^{\mathrm{a}}$ & $23.50 \mathrm{~F} / \mathrm{T}$ & \multicolumn{2}{|c|}{$(1,410$ 円 $/ \mathrm{T})$} & - \\
\hline 運 転 費 & $69.87 \mathrm{~F} / \mathrm{T}$ & \multicolumn{2}{|c|}{$(4,190 \mathrm{H} / \mathrm{T})$} & - \\
\hline 計 & $108.0 \mathrm{~F} / \mathrm{T}$ & \multicolumn{2}{|c|}{$(6,480$ 円 $/ \mathrm{T})$} & $95 \mathrm{~F} / \mathrm{T}$ \\
\hline & $76.0 \mathrm{~F} / \mathrm{T}$ & \multicolumn{2}{|c|}{$(4,560$ 円 $/ \mathrm{T})$} & $37 \mathrm{~F} / \mathrm{T}$ \\
\hline NET COST & $32.0 \mathrm{~F} / \mathrm{T}$ & \multicolumn{2}{|c|}{$(1,920$ 円 $/ \mathrm{T})$} & $58 \mathrm{~F} / \mathrm{T}$ \\
\hline 収入内訳 & $\begin{array}{c}\text { (蒸気) } \\
57.2 \mathrm{~F} / \mathrm{T} \text {. }\end{array}$ & $\begin{array}{l}\text { (電気) } \\
16.3 \mathrm{~F} / \mathrm{T} \text { 、 }\end{array}$ & $\begin{array}{l}\text { (その他) } \\
2.5 \mathrm{~F} / \mathrm{T}\end{array}$ & $\begin{array}{l}\text { (蒸気)（電気）（その他） } \\
28 \mathrm{~F} / \mathrm{T} \quad 7(") 2(")\end{array}$ \\
\hline \begin{tabular}{|l|} 
壳スチーム価格 \\
売 電 力 価 格
\end{tabular} & \multicolumn{3}{|c|}{$\begin{array}{c}39.38 \mathrm{~F} / \mathrm{T} \text { 蒸気 (約 } 2,400 \text { 円 } / \mathrm{T}) \\
0.11 \mathrm{~F} / \mathrm{KWH}(6.6 \mathrm{KWH})\end{array}$} & $\begin{array}{l}21 \mathrm{~F} / \mathrm{T} \text { 蒸気 } \\
0.06 \mathrm{~F} / \mathrm{KWH}\end{array}$ \\
\hline
\end{tabular}

注 a) ムリノ一工場では, 15F/Tである。

b) 1975 年值は, 1976 年あき缶問題訪欧調查恻報告書による
円表示は, 1 F当たり 60 円して計算。

T I R U 所属の工場は，次の 4 つである.

$$
\begin{aligned}
& \text { サントワン工場 } \\
& \text { イッシイ工場 } \\
& \text { イブリ工場 } \\
& \text { ロマンヴィル工場（現在は中継基地として機能） }
\end{aligned}
$$

\subsection{1 サントワン工場}

1937 年に計画されたが, 戦後の経済的困難から, 完 成は 1954 年となった.

ボラン式炉 4 基で, 能力は $12 \mathrm{~T} / \mathrm{H} \times 4$ 基 $=48 \mathrm{~T} / \mathrm{H}$, 回収ボイラ 4 基, 蒸気条件 $20 \mathrm{Bar}, 240^{\circ} \mathrm{C}$.

廃熱ボイラは, $15 \mathrm{~T} / \mathrm{H} \times 4=60 \mathrm{~T} / \mathrm{H}$ の能力をもち, $1,200 \mathrm{KW}$ スチームタービシ 1 基をもって，所内用電力 をまかなっている．蒸気をCPCU（パリ暖房公社）上 ASTHOM へ供給している. スチームタービンと発電 機は 1976 年に設置された。

\subsection{2 イッシィーレームリノー工場}

1965 年に完成した. マルチン式炉 4 基, 能力 $19 \mathrm{~T} / \mathrm{H}$ $\times 4$ 基 $=76 \mathrm{~T} / \mathrm{H}$ （公称 $68 \mathrm{~T} / \mathrm{H} ）$ で, 廃熱ボイラ 4 基が ある.

蒸気条件は, $52 \mathrm{Bar}, 410^{\circ} \mathrm{C}$, 合計 $160 \mathrm{~T} / \mathrm{H}$ の能力 をむつ.

9,000 KW の背圧タービンジェネレーターと, 16,000 $\mathrm{KW}$ の復水タービンジェネレーターを設置している.

電力は, 所内使用分の外は EDF に売られ, 蒸気 はCPCUへ売られる。

\subsection{3 イブリー工場}

1969 年に, 旧設備に代わって隣接地に設置された。 マルチン式炉 2 基, 能力 $50 \mathrm{~T} / \mathrm{H} \times 2$ 基 $=100 \mathrm{~T} / \mathrm{H}$ 廃熱ボイラー 2 基をむつ。
蒸気条件 $80 \mathrm{Bar}, 470^{\circ} \mathrm{C}$, 合計 $260 \mathrm{~T} / \mathrm{H}$ の能力で ある。

64, $000 \mathrm{KW}$ の抽気復水タービンジェネレーターを設 置している.

電力は, 所内使用の他は EDF 亿売却している. 抽 気スチームは, CPCUへ売却される（最大 $150 \mathrm{~T} / \mathrm{H}$ ).

\subsection{4 ロマンヴィル工場}

1969 年，イブリー工場稼動後, 焼却工場は老朽化の ため停止した。 その後, 1975 年迄農業向け土壌改良有 機肥料の生産に当てられてきた（70,000 T/年の処理 能力).

現在は, 新しい工場の建設用地として考えられてお り，輸送中継基地としての役割をあつに過ぎない．

\section{5 焼却による回収エネルギー及び副産物}

1979 年回収エネルギーは, 石油換算 200,000 トン相 当であった.

(1) T I R Uのでみ焼却工場で使用した余りの蒸気は, 直接蒸気の形でパリ市暖房公社 (CPCU) と, サント ワンの AS THOM（機械メーカー）の工場に契約にあ とずいて送られる.

(2) 回収電力の内, 余剩分は計画に基づき（週間計画） フランス電力公社 $(\mathrm{EDF})$ の電力網に送られる.

（3）スラグとしての焼却後の固体残留物は，焼却量の

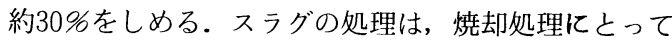
無視出来ない負担となっている.

スラグの有価物としての利用は, 従来から路床の整 備に用いられていたが, 1976 年以降, 路盤全体に用い られるようになり，軌道にのってきている．現在では， 一般道路の基礎にも用いることが検討されている. 
表6 TIRUのごみ処理処分状況（数值は年内合計值）

\begin{tabular}{|c|c|c|c|c|}
\hline & & 1975 & 1977 & 1979 \\
\hline ごみ引受量 & $\begin{array}{cccc}\text { パ } & \text { 市 } \\
\text { パリ } & \text { 以 } \\
\text { 市 } & \text { 特殊 事 業 所 } \\
\text { 小 } & & \text { 計 }\end{array}$ & $\begin{array}{r}(\mathrm{T}) \\
962,535 \\
610,509 \\
66,117 \\
1,639,161\end{array}$ & $\begin{array}{r}(\mathrm{T}) \\
987,955 \\
599,521 \\
58,209 \\
1,645,685\end{array}$ & $\begin{array}{r}(\mathrm{T}) \\
1,028,465 \\
592,128 \\
73,065 \\
1,693,658\end{array}$ \\
\hline 処理処分量 & $\begin{array}{c}\text { サン・トワン工場 } \\
\text { イッシ ッ } \\
\text { イブリー } \\
\text { 小 } \\
\text { 投雍埋立. 他 }\end{array}$ & $\begin{array}{r}(\mathrm{T}) \\
376,590 \\
562,807 \\
629,573 \\
1,568,970 \\
71,910\end{array}$ & $\begin{array}{r}(\mathrm{T}) \\
333,375 \\
526,656 \\
597,779 \\
1,457,810 \\
187,875\end{array}$ & $\begin{array}{r}(\mathrm{T}) \\
350,650 \\
568,000 \\
648,020 \\
1,566,670 \\
126,988\end{array}$ \\
\hline $\begin{array}{c}\text { 電 力充却 量 } \\
(\mathrm{EDP} 八)\end{array}$ & $\begin{array}{ccccc}\text { イ ッ シ } & \text { I場 } \\
\text { イブリ } & \text { ＂ } \\
\text { 小 } & & \text { 計 }\end{array}$ & $\begin{array}{c}\text { (MWH) } \\
44,041 \\
73,175 \\
117,216\end{array}$ & $\begin{array}{l}\text { (MWH) } \\
41,483 \\
69,710 \\
111,193\end{array}$ & $\begin{array}{c}\text { (MWH) } \\
55,975 \\
96,109 \\
138,713\end{array}$ \\
\hline $\begin{array}{l}\text { 蒸 気 売 却 } \\
\text { (CPCU及び } \\
\text { ASTHOM社へ) }\end{array}$ & $\begin{array}{c}\text { サン・トワン工場 } \\
\text { イッ シ イ " } \\
\text { イブ リー } \\
\text { 小 }\end{array}$ & $\begin{array}{r}(\mathrm{T}) \\
415,295 \\
743,799 \\
852,057 \\
2,011,151\end{array}$ & $\begin{array}{r}(\mathrm{T}) \\
471,534 \\
702,378 \\
836,607 \\
2,013,519\end{array}$ & $\begin{array}{r}(\mathrm{T}) \\
493,178 \\
858,872 \\
927,707 \\
2,279,777\end{array}$ \\
\hline ス グ志却 & $\begin{array}{c}\text { サン・トワン工場 } \\
\text { イッ シ イ " } \\
\text { イブリ - " } \\
\text { 小 }\end{array}$ & $\begin{array}{l}\text { 不 明 } \\
\text { 㔭 }\end{array}$ & $\begin{array}{r}(\mathrm{T}) \\
26,603 \\
125,663 \\
170,477 \\
321,743\end{array}$ & $\begin{array}{r}(\mathrm{T}) \\
82,296 \\
164,607 \\
186,331 \\
433,234\end{array}$ \\
\hline くず鉄 売 却 & $\begin{array}{ccccc}\text { イッ シ } \\
\text { イブリー } \\
\text { 小 } \\
\text { 小諹 }\end{array}$ & $\begin{array}{l}\text { 不 明 } \\
\text { 不 明 }\end{array}$ & $\begin{array}{r}(\mathrm{T}) \\
9,586 \\
8,671 \\
18,257\end{array}$ & $\begin{array}{r}(\mathrm{T}) \\
14,979 \\
7,001 \\
21,980\end{array}$ \\
\hline
\end{tabular}

1975年：1976年あき缶処理対策協会，沙欧調查報告書による.

(4) くず 鉄

スラグから，磁気分離により選別分離され，回収屑 鉄として売却している.

屑鉄は，製鋼工場に供給している。

(5) フライアッシュ

“採石局”により, パリ地区で採石後の跡地の緑地 保全のため, 跡地を埋めるのに使用されている.

以上の状況を表 6 亿示した。

\section{6 操業状況}

各工場毎の収集地域割が決められている.

しかし, 定期補修点検のため停止が必要である。停 止は主として，廃棄物の少ない 7 月，8月に行われる. 収集車からの受入れは，一応停止している工場のピッ 卜に受入れられ, 夜間に, 稼動している工場へ移送さ れる（収集と輪送の円滑化のため）。また，焼却能力が 追いつかないときは，1 部管理投棄処分される.
（1）ごみ量の変化（T I R U 引取量） 19751977

$1,639,000$ トン $1,646,000$ トン $1,694,000$ トン
(1.00)
(1.0043)
(1.0335)

(2) ごみ質変化

パリ地区のごみ組成変化を表 7 亿示す.

ごみ量はゆるやかに増加し, 発熱量の高いものの比 率が増加し, 相対的に炉の能力を低下させている.

\section{8 イブリー工場の設備概要および運転概要}

イブリー工場の概要は，多くの説明書があるが，今 回入手の資料をもとに整理してみる.

\subsection{1 設計諸元}

年間処理廃棄物 $600,000 \mathrm{~T} /$ 年

設計でみ発熱量 MAX 2,500 kcal/kg

MIN 1,250 "

AVE 2,000 " 
表 7 パリ地区でみ組成(重量\%)



$40 \mathrm{~T} / \mathrm{H}$ 基 $\left(\mathrm{H}_{\mathrm{l}}=2,500 \mathrm{kcal} / \mathrm{kg}\right)$

$50 \mathrm{~T} / \mathrm{H}$ 基 $\left(\mathrm{H}_{1}=2,000 "\right.$ " )

(平均稼動率 $68 \% ， 250$ 日/年)

ボイラ能力 $126 \mathrm{~T} / \mathrm{H}$ 基

ボイラスチーム条件 $96 \mathrm{Bar}, 470{ }^{\circ} \mathrm{C}$

\subsection{2 設備内容}

投入ゲート $8.5 \mathrm{mGL}, 12$ ゲート

ゴミピット $\quad 9,000 \mathrm{~m}^{3}\left(\operatorname{MAX} 1,800 \mathrm{~m}^{3}\right)$

クレーン POLYP TYPE $6 \mathrm{~m}^{3} 2$ 基（投入は自

動)

炉

2 基, マルチン

投入ホッパー出口寸法 $1.5 \mathrm{~m} \times 12.8 \mathrm{~m}$

グレート $6 \mathrm{SECT} \times 19 \mathrm{STEP}$

$\left(12.8 \mathrm{~m} \times 10 \mathrm{~mL}=128 \mathrm{~m}^{2}\right)$

アッシュ排出 $11 \mathrm{~T} / \mathrm{H} \times 2$ 基

ボイラ（ 2 基）

スチームドラム $1.7 \mathrm{~m} \phi \times 15.4 \mathrm{~mL}$

水ドラム $\quad 1.3 \mathrm{~m} \phi \times 15.4 \mathrm{~mL}$

伝熱面積

$$
\begin{aligned}
& \text { 蒸 発 部 } 1,365 \mathrm{~m}^{2} \\
& \text { 水冷壁部 } 1,360 \mathrm{~m}^{2} \\
& \text { スーパーヒーター } 2,000 \mathrm{~m}^{2} \\
& \text { エコノマイザー } 4,600 \mathrm{~m}^{2}
\end{aligned}
$$

ポンプ

$800 \mathrm{~m}^{3} / \mathrm{H} \times 2$ 基 工業用水供給ポンプ

$8,000 \mathrm{~m}^{3} / \mathrm{H} \times 2$ 基 冷却水循環ポンプ

電気設備 $5,500 \mathrm{~V}$

$380 \mathrm{~V}$

給水ポンプ

蒸気駆動給水ポンプ $\quad 4$ 基

電力駆動給水ポンプ 4 基
（スタートアップ用，緊急用）

タービン

3 段抽気復水夕ービン

蒸気条件 $75 \mathrm{Bar}, 470{ }^{\circ} \mathrm{C}$

蒸気負荷 $255 \mathrm{~T} / \mathrm{H}$

抽気条件 $21 \mathrm{Bar}, 30 \sim 230 \mathrm{~T} / \mathrm{H}$

$$
\begin{aligned}
& 3 \mathrm{Bar} \\
& 0.8 \mathrm{Bar}
\end{aligned}
$$

復水条件 $45.7 \mathrm{mmHg}$

ジェネレーター

出 力 $64,000 \mathrm{KW}, 3,000 \mathrm{RPM}$

減圧, 減湿器 $200 \mathrm{~T} / \mathrm{H} \quad(75 \mathrm{Bar} \rightarrow 21 \mathrm{Bar})$

灰ピット $6,000 \mathrm{~m}^{3}$

吸引ファン, 2 基 $490,000 \mathrm{~N} \mathrm{~m}^{3} / \mathrm{H}$

押込ファン, 2 基 260,000" “燃焼空気用)

冷却ファン, 2 基 150,000 ”

電気集じん機, 2 基 95\%除去, 2 セクション

煙 突 $100 \mathrm{mH}(17 \mathrm{~m} / \mathrm{s}$ 排出, 最大 $29 \mathrm{~m} / \mathrm{s})$

\subsection{3 運転概要}

空気は $80^{\circ} \mathrm{C}$ 亿予熱されて，炉に供給される. 投入ご みは, 平均 $35 \%$ の水分を含む (紙は約 $40 \%$ ). 燃焼ゾー ン出口温度 $900 \sim 950^{\circ} \mathrm{C}$ でコントロールしている. 1 次 空気は, 42個の風箱に供給され， 2 次空気は 4 列の， ズル（燃焼室下部）から供給される．ボイラー出口温 度は, $250^{\circ} \mathrm{C}$ である. CPCUへは $15 \sim 20 \mathrm{Bar}\left(280^{\circ} \mathrm{C}\right)$ で 抽気蒸気が送られる。送気能力は $150 \mathrm{~T} / \mathrm{H}$ である.

Super Heater 部の腐蝕は, 特殊耐酸セメント (CEC 社, スパノリット) で被覆して防止している. 被覆に かかわらず, ボイラ能力を維持するため, 伝熱パネル を追加した．運転結果は良好である.

イブリーは, RC/BRICK の煙突が腐蝕による倒壊 の恐れが出て来たため, 改造, 取換中である. ガス浸 
透凝縮による酸腐蝕である.

現在 1 本の煙突の内面レンガをはがし，煙突の内面 （腐蝕面）をけずり，新たにセメントにて補強し， 内部に鋼管煙突 2 本を入れる計画である.旧煙突は, 鋼管煙突のサポート用に用いる，そのため，現在は既 設煙突の外側に 2 本の仮設煙道をだかせて運転して いる.

現在運転人員は 175 名である.

イブリーでは， 2 段磁選により 2 種類の回収鉄を取 り出している.

フランスでは, 脱臭の問題から燃焼ガス温度 $750^{\circ} \mathrm{C}$ 以上， 2 秒以上保つよう規制されている.

タービントリップの場合は, バイパスの減湿減圧器 を通して，蒸気供給を行う。さらにまた，300 T/Hの 高压コンデンサーを用いて, 蒸気が余るときのバック アップをする.

\section{資 料}

1. Usine d'IVRY

2. $\mathrm{CPCU}$

3. LE SERVICE DU TRATTEMENT INDUSTRIEL DES RESIDUS URBAINS (TIRU)

\section{6. パリ市熱供給公社の状況}

\section{1 概 要}

パリ市は， 7 か所の CPCU工場で生産した蒸気と, 3 か所のごみ焼却場からの蒸気をパリ市の地域暖房用 に供給している。

CPCUのコントロールセンターは BERCY 地区の工 場である. Controll HAT は OPERA 地区である (ほ ぼパリの中心に位置する). CPCUはパリ市とフラン ス電力公社 (EDP) の共同出資会社であり，パリ市の 出資が多い.

工場は，パリ周辺地区に工場，パリ市内に工場，配 管網を力バーし，各工場の休止においてもバランスが とれるよう配置されている, 供給網は,

$\begin{array}{rrr}1972 \text { 年 } & 1976 \text { 年 } & 1979 \text { 年 } \\ 200 \mathrm{~km} & 230 \mathrm{~km} & 300 \mathrm{~km} \text { 弱 }\end{array}$

であり, 下水道網の約 $1 / 10$ 程度の全長をむっている.

(1) CPCUの蒸気生産能力

$$
1976 \text { 年 } 1979 \text { 年 }
$$

$\begin{array}{lrr}\text { CPCU } & 2,510 \mathrm{~T} / \mathrm{H} & 2,660 \mathrm{~T} / \mathrm{H} \\ \text { その他 (TIRU) } & 280 \mathrm{~T} / \mathrm{H} & 280 \mathrm{~T} / \mathrm{H} \\ \text { 計 } & 2,790 \mathrm{~T} / \mathrm{H} & 2,940 \mathrm{~T} / \mathrm{H}\end{array}$

（2）年間供給量
1976 年

1979 年

$\begin{array}{cll}\text { CPCU } & 4,347 \mathrm{~T} / \text { 年 } & 4,784 \mathrm{~T} / \text { 年 } \\ \text { その他 } & 1,958 \mathrm{~T} / \text { 年 } & 2,124 \mathrm{~T} / \text { 年 } \\ \text { 計 } & 6,305 \mathrm{~T} / \text { 年 } & 6,908 \mathrm{~T} / \text { 年 }\end{array}$

(3) ピーク供給量

時間当たり（12 月末） $2,100 \mathrm{~T} / \mathrm{H}$

1 日当たり $44,000 \mathrm{~T} /$ 日

(日平均 $1,812 \mathrm{~T} / \mathrm{H}$ )

\section{(4) 燃 料}

重油主体で, 1 部 LA VILLETTE 工場では石炭を 使用しており，石炭を増加するポリシーである. 1979 年の石炭使用量は 32,000 トンで燃料換算では, 全体 の $5 \%$ 亿相当する.

(5) 蒸気単価 (CPCUの売値)

1979 年 $\quad 60 \sim 70 \mathrm{~F} / \mathrm{T}$

1977 年 $\quad 47 \mathrm{~F} / \mathrm{T}$

1975 年. $\quad 45 \mathrm{~F} / \mathrm{T}$

(6) 蒸気単価（TIRUの CPCUへの売值）

1979 年 $\quad 40 \mathrm{~F} / \mathrm{T}$

1975 年 $\quad 21 \mathrm{~F} / \mathrm{T}$

ここ数年設備の増強は, 周辺の状況より停滞してお り,グリネル工場の $150 \mathrm{~T} / \mathrm{H}$ の堌強が最も新しい.

供給量は, 毎年新期需要拡大により, 年率 $5 \%$ 程度 の伸びをみている.（主に新築の建物による拡大が伸

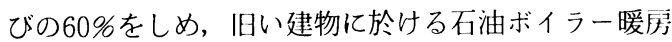
からの転換である.)

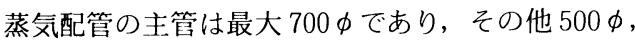
$450 \phi, 300 \phi$ 等である.

石油ショックは, CPCUに新たな対応を要求し, CPCU は次の如き対応をしている. すなわち, (1) 1 次 燃料の多様化 (石炭のウェイトアップ), (2)新規需要 の拡大による成長, (3)石油価格上昇による蒸気売值の アップ.しかし，乙れらは他の熱源である電気，ガス が政府の厳しい統制にあり，エネルギー上の競争の点 で困難を来している。

CPCUは政府と協力して, パリ地域で熱エネルギー を生産し，供給する最良の方法を見出すべく研究開発 を行っている. 当面は石炭利用の拡大である.

\section{2 グリネル工場の概要}

(1) 能 力 ボイラ $190 \mathrm{~T} / \mathrm{H} \times 3$ 基 $=570 \mathrm{~T} / \mathrm{H}$ $75 \mathrm{~T} / \mathrm{H} \times 3$ 基 $=225 \mathrm{~T} / \mathrm{H}$

計 $795 \mathrm{~T} / \mathrm{H}$

(2) 設置 屋 内 パリ市再開発地区に立地している. 
(3) パイプライン

$500 \phi \times 4$ 本でメインパイプライン網に接続している.

(4) 平均蒸気条件

送気元 $235^{\circ} \mathrm{C} \quad 18 \mathrm{Bar}$

压力条件は, BERCYのコントロールセンターの指 令にもとづき，16〜20 Bar 位の間で変動する.

（5）生産量およびボイラをいくらの負荷で稼動させる かは, すべて BERCY コントロールセンターの指令に あとづいて行われる.

(6) 蒸気は末端では $210 \sim 215^{\circ} \mathrm{C}$ 位に下る.

（7）凝縮した蒸気は，各地区のポンプステーションか ら CPCUの各工場へ返送される. 温度は約 $50 \sim 60^{\circ} \mathrm{C}$ である。

（8）パリ年の暖房システムは，CPCUより蒸気で送り， 各ユーザー毎に温水との熱交があり，スチームドレン を各ユーザー毎に計量器で計測し，使用料金を計算す る仕組みになっている。

すなわち, 暖房会社が温水の熱交をもち, 温水循環 により熱供給を実施している方式とは異なっている。
（9）使用燃料は，1\%以下硫黄（TBTS. №.2, 日本で のA重油相当）である.

パリ市内では，1\%以下硫黄の油に使用が規制され ている。

パリ市域外では， $2 \%$ 硫黄の規制となっており CP CUのイブリー工場は $2 \%$ 硫黄でよい.

(10) 油の貯蔵タンク

油は屋内タンク眝蔵で,

$$
\begin{aligned}
& 2800 \mathrm{kl} \times 3=8,400 \mathrm{kl} \\
& 1600 \mathrm{kl} \times 1=1,000 \mathrm{kl} \\
& \text { 合 計 } 10,000 \mathrm{kl}
\end{aligned}
$$

家屋が建て込んだ土地で，日本では一般には考えら れないような狭い場所に貯蔵されている。

(11) 訪問中は，定修で全部停止していたが，需要の低 下する時期であり，イシイおよび他工場のバックアッ プで充分であるとのととであった。

(12) 運転体制は，4 組 3 交替である. 人員は約 300 人 である。

\section{わかり易い公害分析・計測基礎講座}

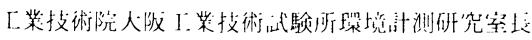

$$
11 \text { 爬利夫編著 }
$$

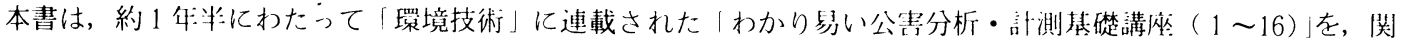
連読者の要望により1州にまとめたものです.

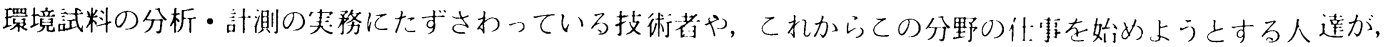

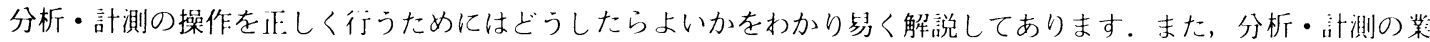
務に直接関係しない力々でも，ての仆事がいかに重要であり，またいかなる理論から組み市てら扎た技術体系であ るかが理解していただけると思います。

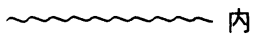

第 1 講 吸光光度法

第 2 講 原子吸光法

第 3 講 けい光光度法

第 4 講 発光分光分析法

第 5 講 けい光X線分析法

第 6 講 ガスクロマトグラフ分析法

第 7 講 ガスクロマトグラフー-質量分析(GC-MS)法

第 8 講 ポーラログラフ分析法
容

第 9 講 イオン電柽法

第10講 サンブリング法

第11講 BOD, CODの测定法

第12講 TOD, TOC の測定法

第13講 浴媒抽出法

第14講 イオン交換法

第15講 滴定法 